\title{
Middle Caddo Whole Vessels from the Ferguson Site (3HE63)
}

Pritam Chowdhury

University of Arkansas

Follow this and additional works at: https://scholarworks.sfasu.edu/ita

Part of the American Material Culture Commons, Archaeological Anthropology Commons, Environmental Studies Commons, Other American Studies Commons, Other Arts and Humanities Commons, Other History of Art, Architecture, and Archaeology Commons, and the United States History Commons

Tell us how this article helped you.

This Article is brought to you for free and open access by the Center for Regional Heritage Research at SFA ScholarWorks. It has been accepted for inclusion in Index of Texas Archaeology: Open Access Gray Literature from the Lone Star State by an authorized editor of SFA ScholarWorks. For more information, please contact cdsscholarworks@sfasu.edu. 


\section{Middle Caddo Whole Vessels from the Ferguson Site (3HE63) \\ Creative Commons License \\ (c) (1) \& 8}

This work is licensed under a Creative Commons Attribution-NonCommercial 4.0 International License 


\title{
Middle Caddo Whole Vessels from the Ferguson Site (3HE63)
}

\author{
Pritam Chowdhury \\ University of Arkansas
}

The Ferguson site (3HE63) is a Caddo ceremonial center in Hempstead County, Arkansas. The Arkansas Archeological Survey and Arkansas Archeological Society excavated Ferguson between 1972 and 1974, under the direction of Dr. Frank Schambach. The site has a middle Caddo Haley phase (A.D. 1200-1400) component consisting of two mounds, several structures, and a small cemetery area, set atop a 2-acre Woodland period Fourche Maline village. One of the mounds included several elite Caddo shaft graves rich with ceramic artifacts. My recent research with Ferguson site collections included a metric and stylistic analysis of whole vessel ceramics from the Haley phase Caddo components. This paper reports on some results of this inventory and analysis.

\section{Introduction}

The Ferguson site (3HE63) is a Caddo mound site in Hempstead County, Arkansas. This site was recorded by the Arkansas Archeological Survey (ARAS) in 1971, and was the focus of salvage excavations lead by Dr. Frank Schambach during the Arkansas Archeological Society's (AAS) annual Field Schools in 1972-1974 (Schambach 1972, 1996; Schambach and Early 1985). During the field schools, two Caddo mounds, a small cemetery area, a Fourche Maline midden, and Early Archaic, and late Paleoindian components were meticulously excavated (Figure 1).

\section{Background}

Joe Weeks and David Keith reported the site to the ARAS in September of 1971. Dr. Frank Schambach was notified in January 1972 when Mound A (which turned out to be a large two-level temple mound) was about to be leveled, for use in the property owner's new raised road to their new house site on the bluff above (Schambach 1972a). Mr. Caroll and Mrs. Glenda Ferguson voluntarily scaled down and halted leveling and landfill operations following Schambach's initial visits and consequent realization of the site's significance.

The Ferguson site was subjected to pothunting in the early decades of the twentieth century, as with most major Caddo sites. Locals claim that a large hole was excavated in the top of Mound A (Schambach 1972a). This early treasure hunting increased the

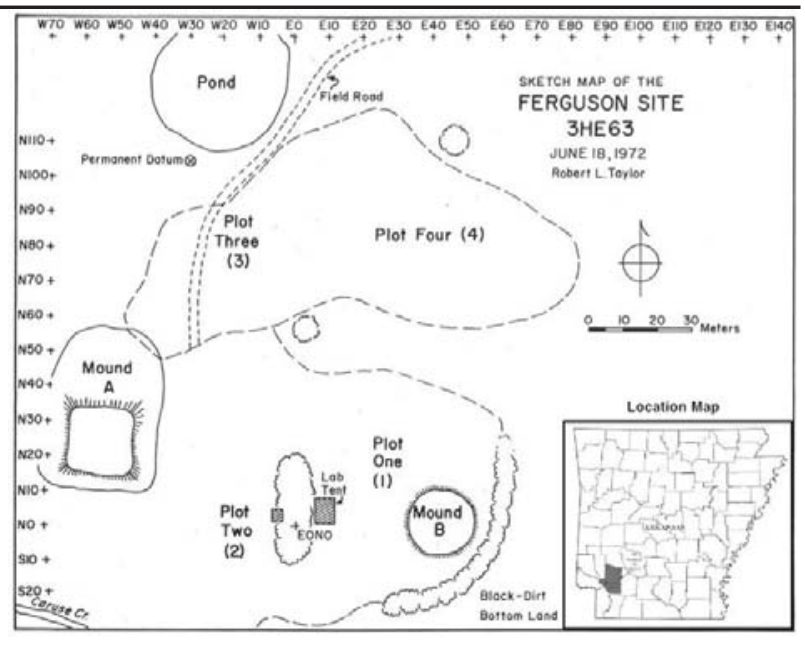

Figure 1. Site plan and location map.

difficulty of interpreting Mound A's stratigraphy. In the 1960s, artifact collectors looted burials along a cemetery area northeast of Mound A. Schambach's investigations revealed that artifacts accompanying the burials were Haley phase Caddo, with at least one grave lot representing a late Caddo use of the cemetery. Mound B was a low inconspicuous dome-shaped structure. Quantities of burned debris and resilient clay atop Mound B may have functioned as a concealment and deterrent to looters, since few potholes penetrated the clay cap, leaving the burials within this mound generally undisturbed. In one case, a pothole intersected the corner of a grave-shaft.

As excavations proceeded, it was revealed that the Ferguson site was a multi-component 2-acre (0.8 ha) site including two mounds. Mound A, in its latest prehistoric manifestation, was a large two-level 


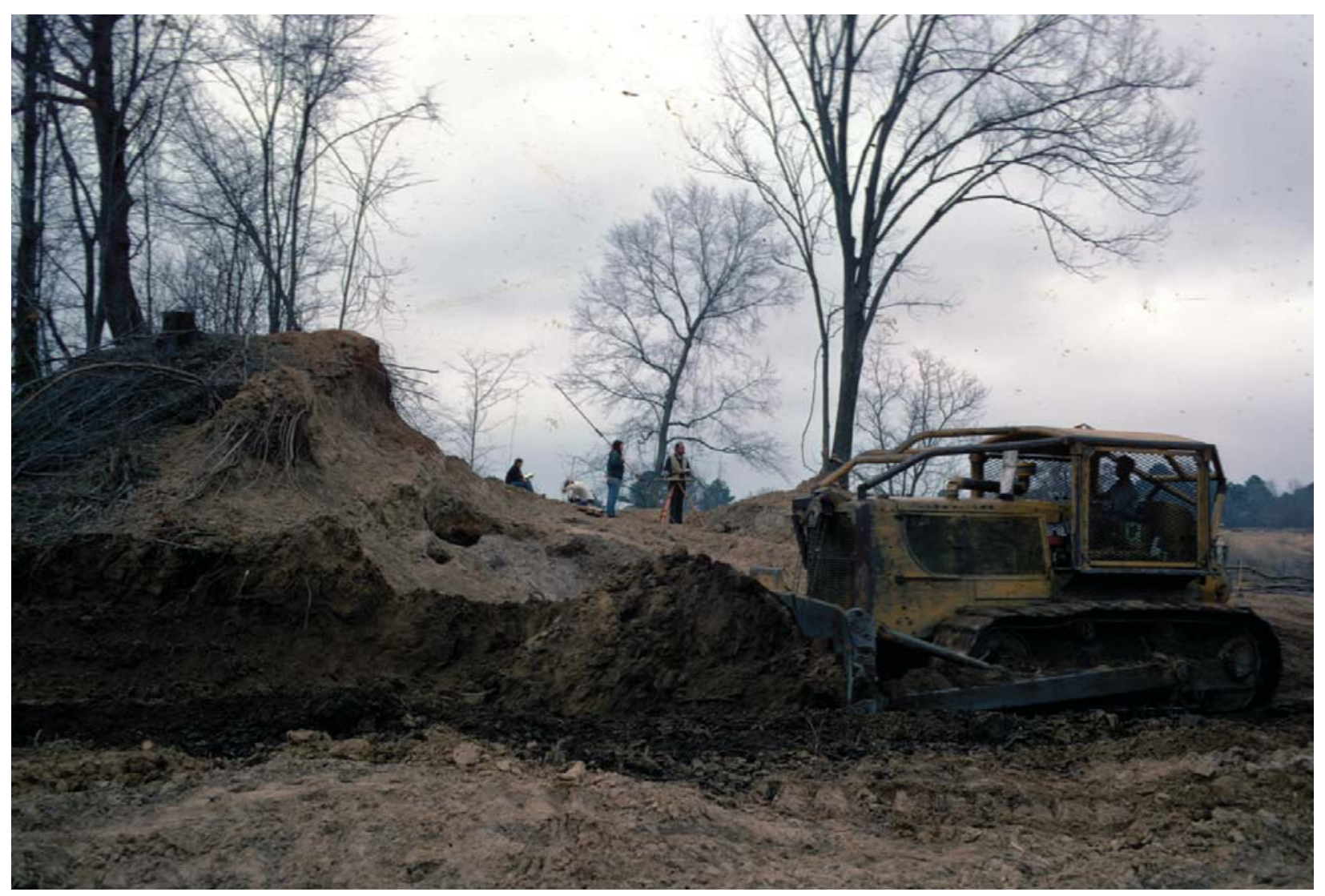

Figure 2. Carol Ferguson leveling Mound A (AAS-SAU file photo 1972-671).

temple mound that dominated the site from the west. Mound B was 280 feet east $(85 \mathrm{~m})$ and slightly south of Mound A. The area between the mounds was level with about a two-foot $(60 \mathrm{~cm})$ deep midden, which had minimal plow disturbance in 1972, no deeper than 4-5 inches $(10-12 \mathrm{~cm})$. The soil in this area was slightly acidic so bone preservation was poor, other than under the mounds. The midden was especially rich beneath the mounds, yielding about a quarter-acre of deposits that had been completely sealed off since about A.D. 1100 (Schambach 1972a).

When the ARAS became involved at the Ferguson site in 1972, the plan was to monitor and document features while the landowner was leveling the site (Figure 2). However, when a greater sense of the site's significance was observed, Schambach convinced the landowners to halt their land-leveling activities. Consequently, the ARAS and AAS conducted extensive salvage excavations over the next three-years.

Haley phase people were the first to initiate mound construction at the Ferguson site similar to
Red River valley Caddo ceremonial centers such as Hatchel, Battle, and Belcher (McKinnon 2013, 2017; Perttula et. al. 2008; Webb 1959). There was an abrupt cultural change and regional diversification that occurred at each of these sites in the Middle to Late Caddo periods. Despite the divergent local traditions that were manifested at these sites and regions, mound building increased to new heights and volumes. The Haley phase may have developed out of the earlier Alto complex, with continuities between it and the earlier Early Caddo period, including the use of shaft burials for certain members of society, sent to the afterlife with relatively rich grave offerings (Suhm et. al. 1954:169-175). Complex mortuary ceremonialism, status ranking of burials, and the organizational control necessary to construct mound centers and suggest that there was a "political and religious hierarchy that operated throughout the Haley [phase] society" (Wyckoff 1974:110). The Texarkana phase followed the Haley phase at the Hatchel site. The Belcher phase followed the Haley phase at the Belcher site. A mixture 
of Texarkana and Belcher phases was found post-Haley phase at the Battle Mound (McKinnon 2008, 2013, 2016).

Clarence B. Moore (1912) spent more time at Haley Place (3MI11), three weeks, than any other site on the Red River (Gopher log, 7-24 February 1912, in Weinstein et al. 2003:65). His data from the site played an important role in the understanding the development of the Caddo cultural sequence in southwest Arkansas and served as the type-site for the Haley focus (now phase) (Krieger 1946; Suhm and Jelks 1962; Weinstein et al. 2003:65). Moore reached the 'Mounds on the Haley Place,' in Miller County, Arkansas the morning of February 7, having already traveled nearly 400 miles up the Red River, with little to show for it. This changed once he reached Haley, where he found three mounds. The first was very eroded and had a contemporary building on it. The second was a rectangular mound with two platforms on it. The third was roughly circular. Moore's excavations into the rectangular mound did not expose any burials and he correctly surmised that it was a base for Caddo structures, like Mound A at Ferguson (Moore 1912; Weinstein, et al. 2003:65). In the third, a circular burial mound similar to Mound B at Ferguson, Moore and crew encountered nine highstatus Caddo burials. At Haley, each of these graves contained the remains of a single individual, interred with a considerable quantity of grave goods including numerous "pottery vessels, conch shell cups, shell beads and disks, fresh water pearls, ceramic pipes, a limestone human-effigy pipe, copper-covered ear spools, and ceremonial celts." The fragmentary pottery sherds were so numerous that Moore was not able to estimate the total number of vessels that were represented in the burials. Weinstein et al. (2003) typed the whole vessels Moore catalogued and illustrated, including examples of what are now known as: Haley Engraved (Moore 1912: Figures 42,49,54-56), Haley ComplicatedIncised (Moore 1912:43,51,53,57, Plate XXXIX), and likely trade vessel Nashville Negative Painted (Moore 1912: Plate XXXVII). All were in association with the Middle Caddo Haley Phase components at the site. Amateur archeologists located two cemeteries at Haley in the 1960s and excavated over 80 burials. Hoffman (1970) reported that most the excavated materials were contemporaneous with the mound burials Moore excavated, but some were slightly later (Hoffman 1970:162-163).

Prior to Moore's visit to Haley, he visited the 'Mound near Sulphur River,' which was in the woods at the time (Moore 1912:527). He wrote very little about what was found there other than the site location and that it contained no burials. The site was later recorded by the ARAS in 1979, as the Myers Mound Site (3MI39). Like Ferguson, the ARAS was at Myers to salvage information as the mound was scheduled to be leveled. This salvage work revealed that the site was a Middle Caddo Haley Phase site that served as platform for the "sacred fire" (Miller 1986; Weinstein et al. 2003:65).

At least two sites that Harrington (1920) excavated in the Little Missouri River drainage, in Hempstead County, the Washington Site (3HE35) and Ozan No. 1 (3HE37), produced artifacts similar to the Haley site. Krieger (1946) utilized the data from these three sites to define the 'Haley Focus' (213- 214). Following this, Haley components were also recognized at Crenshaw on the Red River (Table 1; Figure 3). Moore was the first to excavate at Crenshaw, followed by Judge Lemley, Glenn Martin, M.P. Miroir, and Schambach. Other sites with Haley components include: 1) the lower component of Hatchel mound in Bowie County, Texas, 2) the cemetery adjacent to Battle Mound at the Handy Site, 3) the lower component at Battle (Krieger and Howard 1948), 4) the lowest level (IV) at Belcher mound, in Caddo Parish, Louisiana (Webb and Dodd 1941; Webb 1948), and 5) East Mound in Clark County, Arkansas, which was excavated by Dr. Robert Proctor of Arkadelphia and the Huddlestons (Suhm and

\begin{tabular}{lll} 
Site \# & Site Name \\
\cline { 1 - 2 } 3CL0021 & East Place \\
3HE0035 & Washington Mounds \\
3HE0037 & Ozan \#1 \\
3HE0040 & Tom Jones Place \\
3HE0063 & Ferguson site \\
3HO0001 & Mineral Springs \\
3LA0001 & Battle Mound \\
3MI0006 & Crenshaw site \\
3MI0011 & Haley Place \\
3MI0039 & Myers Mound \\
3PI0013 & Davis Farm
\end{tabular}

Table 1. Known Haley phase sites in Southwest Arkansas. 


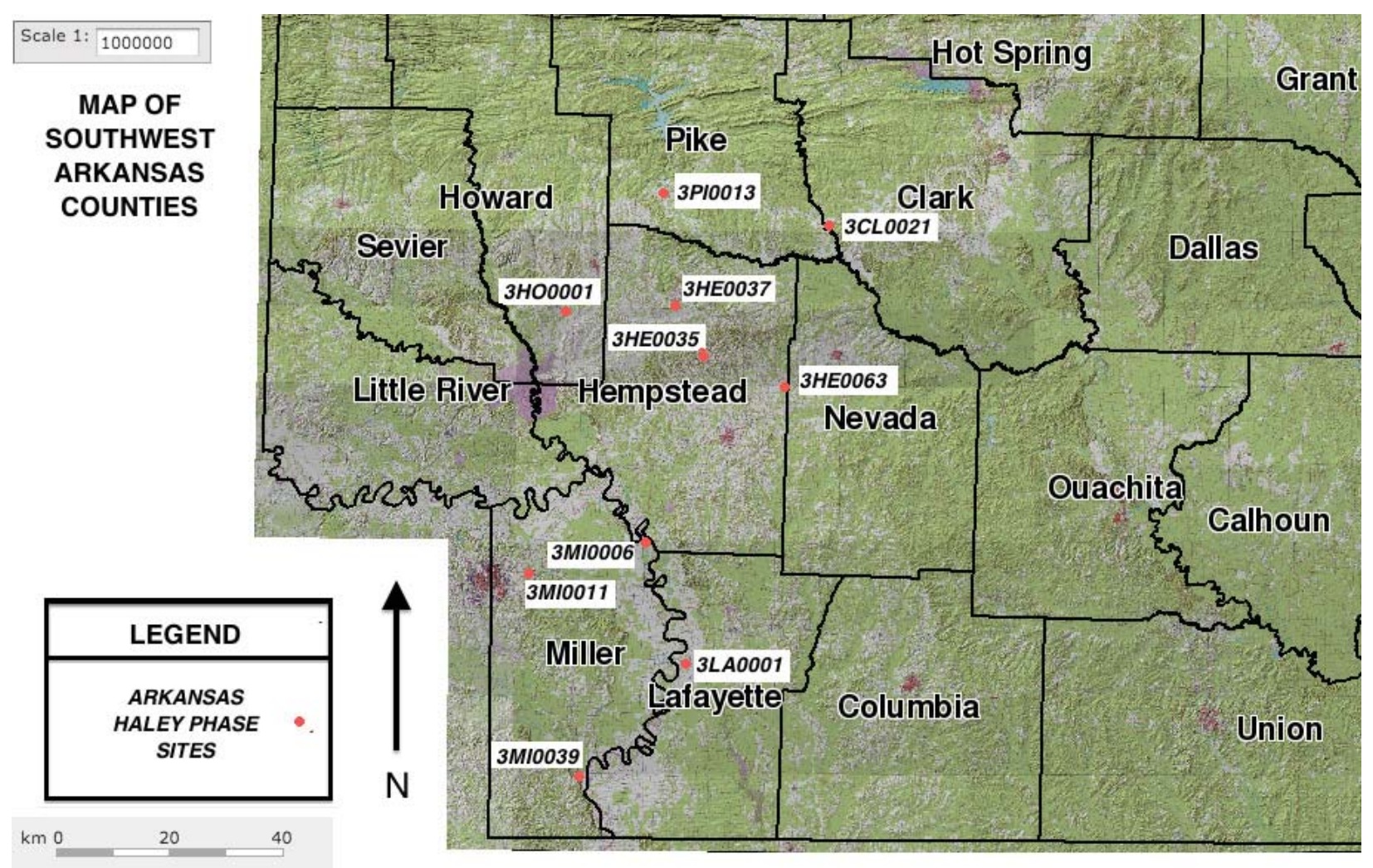

Figure 3. Map of known sites with Haley Phase component in southwest Arkansas.

Jelks 1954:170). Newell and Krieger (1949: Figures 63$65)$ illustrated the ceramic vessels from the East site and described how they diverged from other Haley Phase sites.

The Haley phase marked the appearance of ceramic features such "as the use of handles (wide strap handles on polished bowls as well as cooking jars), appliqué fillets and nodes, brushing on jar surfaces as alternative to incising, fairly extensive use of red filming, and effigy vessels" in the Caddo ceramic tradition (Suhm and Jelks 1962:171). These elements are almost completely absent at Spiro, Gahagan, and Alto. The Sanders phase was contemporaneous with the Haley phase based on trade vessels appearing bi-directionally between the regions (Newell and Krieger 1949; see also Schambach 1997, 1998).

Numerous elite Caddo shaft graves excavated at the Ferguson site contained whole ceramic vessels diagnostic of the Haley phase. These grave lots contained pottery vessels of established Caddo pottery types, such as Adair Engraved, East Incised, Friendship Engraved, Glassell Engraved, Haley Complicated Incised, Haley Engraved, Hempstead Engraved, Karnack
Brushed Incised, Kiam Incised, Mineral Springs Engraved, Moore Noded, Pease Brushed-Incised, and Sinner Linear Punctate (see Brown 1996; Early 1988; Suhm and Jelks 1962). Vessel forms included bottles, bowls, and jars.

\section{Treatment of the Ferguson site whole vessels}

During the early 1970s excavations at Ferguson, soil was carefully removed from around the complete vessels in the field. No attempt was made to completely clean the surfaces. Wisely, archeologists hoped this would help retain any pigments or other materials adhering to the outer surfaces of them. In general, fineware vessels and sherds were not washed in the field lab. These were carefully cleaned and curated at the lab at ARAS-Southern State College (now Southern Arkansas University) in Magnolia. As best they could, ceramic samples were restored and all the fitting sherds of individual vessels were glued back together. This ceramic assemblage has remained unstudied since that time. 
During this study, I collected metric data from the Ferguson site vessels by utilizing the ceramic documentation form developed by the ARAS Registrar Office. This form was created as part of a grant project geared toward documenting whole vessels curated by the University of Arkansas Museum, following the guidelines of the Native American Graves and Repatriation Act (NAGPRA). The whole vessels from grave contexts at Ferguson are subject to NAGPRA repatriation by the Caddo Nation of Oklahoma, although they have not been claimed from the ARAS at this time. The structure and categories of this form were chosen due to its comprehensiveness and for the sake of comparability. This form was based on analytical techniques and guidelines developed by Prudence Rice (1987) and are thoroughly outlined in Pottery Analysis: A Sourcebook. The version of the paper form I utilized was revised by Dr. Leslie Walker on April 10, 2009. Additionally, a manuscript on file at the ARAS Registrar Office entitled "Documentation of Ceramic Vessels as part of a NAGPRA Grant," by Khawam (2003), was consulted as a guide for recording standards.

Following the completion of these paper forms, I developed a digital database in the Filemaker ProBento (version 3.06). I inputted all the data from the paper copy forms into the digital database, which offered numerous opportunities for adding media content, and broad sorting, querying, and exporting options (i.e., forms, tables, spreadsheets, comma separated files, PDF documents, etc.). Some fields of my database form vary slightly from the original paper form but maintained all key information while providing additional details, fields, and media. The initial part of the form includes: accession number, vessel number, site name, facility or location, associated burial(s), collection area, cultural affiliation, type, variety, and bibliographic citation.

The vessel condition was recorded as complete, partial, or sherds. Complete and partial vessels were further delineated as reassembled (long term or glued) or reassembled (short term or taped). Overall vessel shape was assessed based on criteria outlined in Anna Shephard's (1956) Ceramics for the Archaeologist. In my study, Ferguson site vessels were sorted as: (1) bottles, (2) bowls, or (3) jars. Bottles included vessels with highly constricted neck openings. Bowls were relatively shallow vessels in which the orifice is either not constricted or slightly constricted. Jars are relatively deeper than bowls, had some constriction at the junction of the rim and body, and usually had more constricted orifices than bowls.

The colors of the exterior, interior, and core of the vessel were recorded using a Munsell Handbook. Then, multiple additional measurements were taken including metric data regarding fields of the vessel, as applicable, which included rim/lip, neck/lip, handle, body, base, appendages, etc. The height, thickness, and orifice diameters were then recorded for each field. An osteological board and line level were used for measuring height. The maximum vessel diameter of each vessel was measured at the widest portion using calipers. The vessel paste was determined based on whether it was compact or crumbly, soft or hard, smooth or silty, and the temper size (fine, medium, or coarse). A crumbly paste was flaky or degraded. In contrast, a compact paste was intact. If the vessel could be scratched with a fingernail, that is a soft paste. Rather than damaging the vessel with a new scratch, I based this assessment on the relative presence and frequency of existing scratches on the vessel. The siltiness of the paste was assessed based on whether any of the body wiped off as powder while it was being analyzed.

Vessels with a smooth paste did not degrade onto gloves, or the lab space while analyzed.

Temper was assessed based on the size and content of the particles utilized for this purpose. Vessels with visible particles smaller than $1 \mathrm{~mm}$ had a fine temper. Medium temper was noted when more than five particles were larger than $1 \mathrm{~mm}$, although most could still be less than $1 \mathrm{~mm}$. Vessels with a coarse temper had particles up to 6-7 $\mathrm{mm}$ in diameter, with the majority being larger than $1 \mathrm{~mm}$ in size. The temper materials were also noted, with clay, grit, bone, and some combinations of these being the most common in the Ferguson site ceramic assemblage. In a few cases, there were no breaks and the temper was not visible through the vessel surface.

Decorative elements on the original interior and exterior of the vessel were then recorded, with non-exclusive categories such as smoothed, burnished, brushed, incised, engraved, etc. A detailed description of the vessel shape was recorded, along with qualitative assessments made visually and quantitative data 
carefully measured with calipers. As applicable, these included vessel height, vessel maximum diameter, rim shape, rim height, rim thickness, rim diameter, rim decoration, rim surface mode/treatment, lip shape, lip thickness, lip shape, lip thickness, lip surface mode or treatment, lip decoration, neck shape, neck height, neck thickness, orifice diameter, neck mid-exterior and base diameters, neck decoration, neck surface treatment, handle shape, handle decoration, body decoration, body shape, body height, body thickness, body diameter, body mode, body surface treatments, base shape, base decoration, base diameter at top and bottom, and base surface treatment. Then, any evidence of predepositional use wear was recorded. Carbonized remains and encrustations observed were examined under a magnifying glass or microscope, recorded, and prepared for additional photo documentation. Following this, any effigies or appendages on the vessel were measured and described in detail. Then, any additional comments, such as grave associations, similar vessels, etc. were further documented. Finally, digitally rendered vessel illustrations, pictures, and design or pattern illustrations were attached to the form.

\section{Ferguson site Whole Vessel Descriptions and Burial Associations}

A total of 42 whole ceramic vessels were documented and analyzed during this study (Table 2). These whole vessels originated in numerous Middle Caddo burial features, except for the pre-Caddo Fourche Maline Burial 14, around the site (Table 3). These include Burial 1-4 (Mound B, Feature 2), Burial 21 (Mound B, Feature 8), Burial 5 (Mound B, Feature 32), Burial 12 (Mound B, Feature 14/15), Burial 14 (Plot 2, Feature 6), Burial 11 (Plot 3, Feature 8), and an Early Caddo grave Burial 9 (Plot 2, Feature 18). Half of the vessels $(n=21)$ originated in Burial 21, an elite Middle Caddo group shaft grave (with two individuals) in the very center of Mound B. Nearly another third of the whole vessels collection came from the Burial 1-4 group burial, which included another Middle Caddo leader with three possible 'retainer graves' accompanying him (see Rose and Powell 1975; Schambach 1972a; Schambach and Early 1985). Burial 5 was another contemporaneous Caddo grave, and had four whole vessels. Burial 9, 12,

\begin{tabular}{lc} 
Type & \# Vessels \\
\hline Adair Engraved & 1 \\
East Incised & 1 \\
Friendship Engraved & 5 \\
Glassell Engraved & 2 \\
Haley Complicated Engraved & 2 \\
Haley Engraved, var. Caruse & 8 \\
Haley Engraved, var. Adams & 1 \\
Haley Engraved & 1 \\
Mineral Springs Engraved & 2 \\
Hempstead Engraved & 2 \\
Karnack Brushed Incised & 1 \\
Kiam Incised & 1 \\
Moore Noded & 1 \\
Pease Brushed Incised & 3 \\
Pease Brushed Incised/Sinner Linear & 1 \\
Punctate combo & 7 \\
Sinner Linear Punctate & 3 \\
Untyped Vessels & 42 \\
\cline { 2 - 2 } &
\end{tabular}

Table 2. Ferguson site whole vessel pottery types.

\begin{tabular}{llc} 
Burial \# & Feature \# & Vessels \\
\hline Burial 1-4 & Mound B, Feature 2 & 12 \\
Burial 21 & Mound B, Feature 8 & 21 \\
Burial 5 & Mound B, Feature 32 & 4 \\
Burial 12 & Mound B, Feature 14/15 & 1 \\
Burial 14 & Plot 2, Feature 6 & 2 \\
Burial 11 & Plot 3, Feature 8 & 1 \\
Burial 9 & Plot 2, Feature 18 & 1 \\
\cline { 2 - 2 } & & 42
\end{tabular}

Table 3. Ferguson site whole vessels by burial feature

and 14 each contained a single whole vessel. Finally, Burial 14 had two untyped plain bottles.

\section{Ferguson Pottery Types and Descriptions}

\section{Adair Engraved var. Adair}

Adair Engraved was distinguished from the original Friendship Engraved type "at the suggestion of Schambach in recognition of the basic difference between the cross-hatched background of the revised Friendship type and the use of cross-hatched panels arranged around the design elements" 


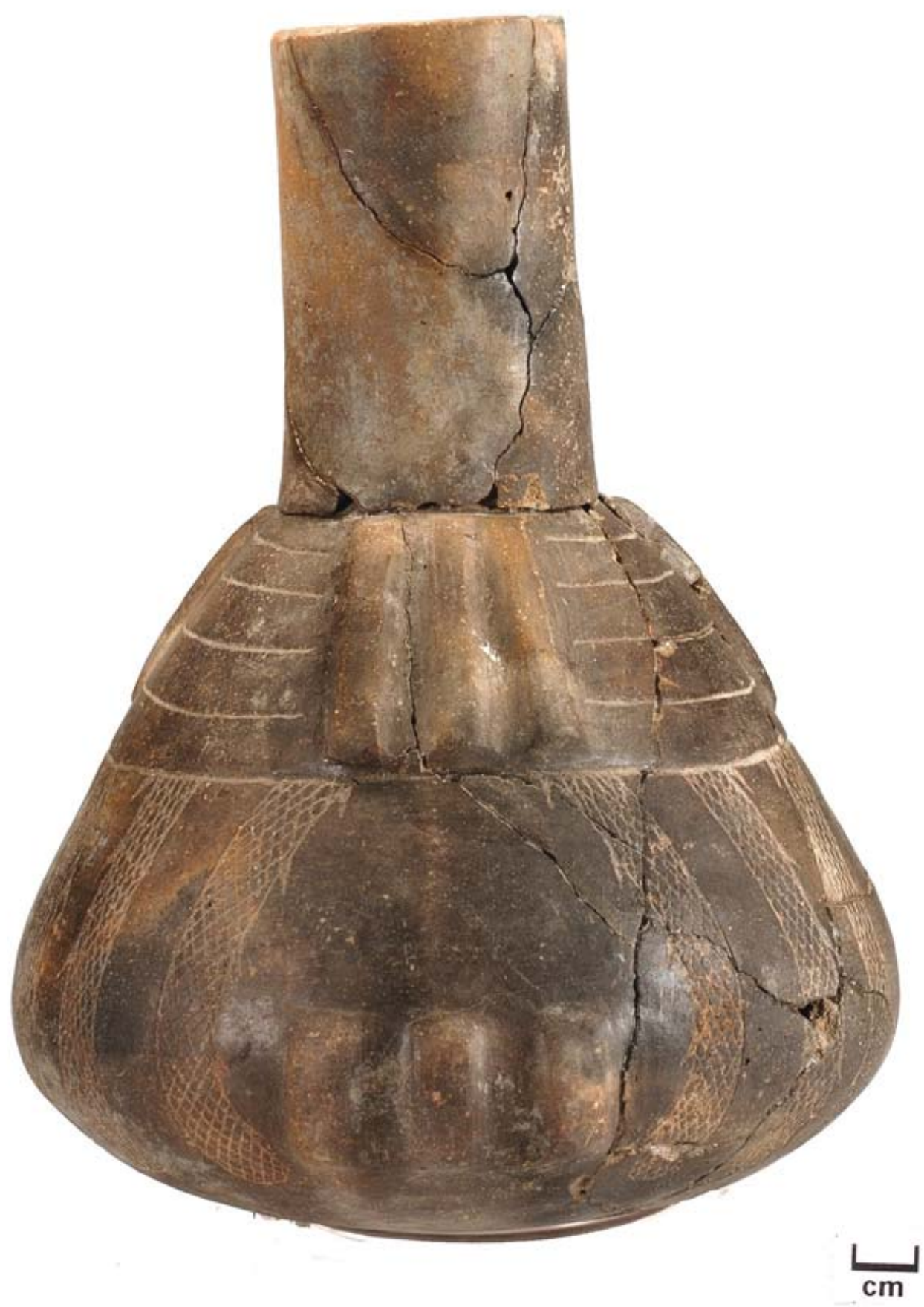

Figure 4. Adair Engraved var. Adair (Vessel 28, Acc. \#: 72-22-1772-18).

(Brown 1996:377). Additionally, Schambach distinguished the variety Adair with its "three to four sets of double or triple short appliqué strips or bosses arranged vertically on the shoulder and body of bottles. The body is decorated with rectilinear to slightly curvilinear bands of cross-hatching placed vertically around the body" (Brown 1996:377).
One bottle and seven sherds of this type were found at the Spiro site. Schambach noted that Adair Engraved var. Adair is found in sites in Pike, Garland, and Henderson counties in Arkansas (personal communication 2010). At Ferguson, a whole bottle of this type and variety (Vessel 28, Acc. \#: 72-22-177218) was found in the Burial 21 (Mound, Feature 8) 


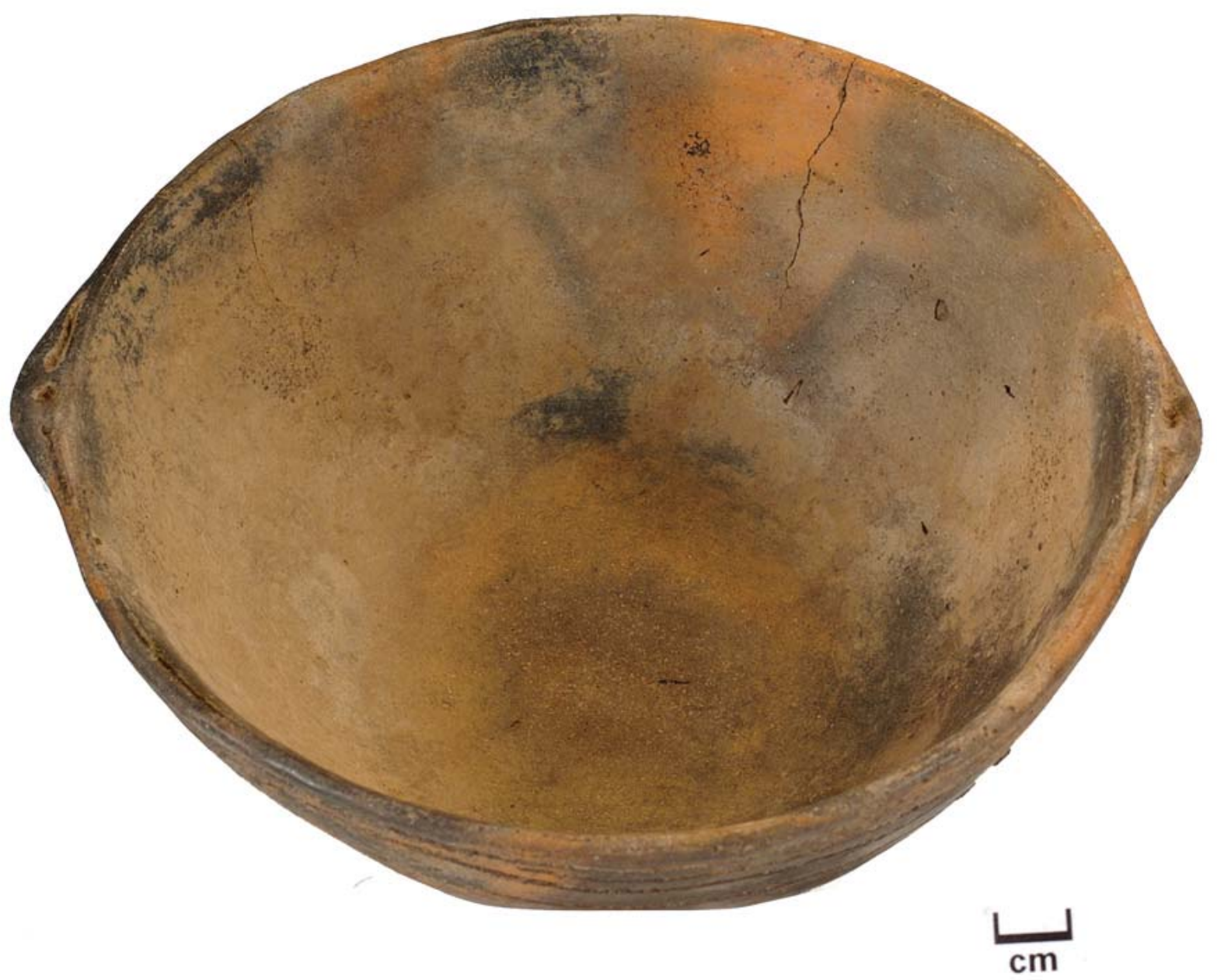

Figure 5. East Incised (Vessel 38, Acc. \#: 72-22-196-1).

grave in association with Haley Engraved var. Caruse. This compound carinated insloping bottle has a flat lip, vertical-insloping neck, and a circular and convex base (Figure 4). The bottle has a predominantly clay temper, with a little bone. The body includes the bottom two components of a tripartate compound vessel. The bottom is engraved with three sets of cross-hatched lines with spurs and three sets of appliqué ridges. The top of body has sets of three sets appliqué ridges and four annular engraved lines running the circumference of the vessel.

\section{East Incised}

East Incised vessels have a fine clay-grit and low sand content temper. The texture is very fine with a color ranging from shades of brown and reddish brown. The red on East Incised vessels may be produced by firing temperature on mottled surfaces or a red slip may be applied. The cores are brown and gray. Vessel surfaces are smoothed but seldom polished (Suhm and Jelks 1962:41).

East Incised vessels are usually small and not over 18-20 cm in height or diameter. Simple bowls have straight, vertical, or convex sides which are recurved and stand "more or less vertical or sloping slightly inward or outward." Rims may have opposed peaks, four peaks, or two opposed tabs built out on side of lip. These tabs "may or may not have small pits sunk in center." Other forms with effigy rim riders, cylindrical, barrel-shaped, and deep bowls with truncated cones have been documented in the East Incised type. Two opposing suspension holes in the rims are a common trait in upright vessels. 
East Incised vessels are decorated with incised lines that are partly or entirely smoothed over. Designs include horizontal lines encircling the vessel rims, "except where they are interrupted by sets of semicircular lines placed under rim peaks or effigy features" (Suhm and Jelks 1962:41). On rare occasions, white pigment is preserved in the lines of East Incised vessels. One bowl of the East Incised type (Acc. \#: 7222-196-1) was excavated from a Caddo burial, Burial 12 (Mound B, Feature 14/15) at the Ferguson site. Human remains from this grave included only fragmentary cranial fragments. The bowl was lying intact on its side with its open end facing toward the west end of the grave. Schambach noted that if "the head of the skeleton was near the pot--what is likely--head would have been toward the [West]" (Schambach 1972b).

Ferguson Vessel 38 (Acc. \#: 72-22-196-1) is an ovaloid bowl with a circular rim with two opposing tabs, a flat lip, and circular and flat base (Figure 5). This vessel was found on its side in Mound B, Feature 14 and was a grave good accompanying Feature 15 from the pre-mound subsoil level. The bowl is grit tempered with some shell and has two opposing rim tabs that have paired excised triangles with an excised circle in the center. The body of the vessel is smoothed with a red slip and has a band of four annular incised lines going from the top of the body to the top of the rim. The bowl has observable wear and is fire-mottled. Black bituminous encrustations are visible on the inside and outside of the vessel.

\section{Friendship Engraved}

Friendship Engraved ceramic vessels are a Caddo fineware that usually have no temper, but sometimes do have small amounts of fine clay-grit or sand in the paste (Suhm and Jelks 1962:45). The texture of these vessels is very fine and compact. Friendship Engraved vessels have a color that ranges from shades of "reddish-brown and gray-brown from light to dark and nearly black" (Suhm and Jelks 1962:45). The surface finish includes a fair to good polish.

Friendship Engraved vessels are nearly all bowls or bottles. Carinated Friendship engraved bowls have shallow bottoms and high rims that are vertical or slant inward or outward slightly. Suhm and Jelks also documented other forms such as simple conical bowls, as well as small jars with squat bodies and the rims pointed outward slightly. In Early's (1989:75-77) revision of this type, Friendship Engraved vessels must have a band running diagonally of placed scrolls against a cross-hatched background.

Ferguson Vessel 32 (Acc. \#: 72-22-1772-26) was excavated from Burial 21 (Mound B, Feature 8) (Figure 6). This carinated bowl has a rounded lip and convex to almost flat bottom base. This sample is grit and bone tempered and is engraved with cross-hatched lines. This vessel is the larger of two Friendship Engraved bowls from Mound B, Feature 8. Ferguson Vessel 29 (Acc. \#: 72-22-1772-19) was also excavated from Burial 21 and is a carinated bowl with a slightly rolled lip and concave base (Figure 7). The sample is grit and bone tempered.

\section{Friendship Engraved, var. Freeman}

In her report on ceramics from the Hardman site, Early (1993:90) distinguished the Freeman variety of Friendship Engraved as "restricted to carinated bowls with convex bodies, no definable bases, nearly straight rims that are vertical or slightly insloping, and very small straight to slightly flaring lips." The decoration on this variety is limited to the rim, consisting of two or three horizontally placed panels that may contain horizontal lines, scroll, and oval elements. The background decoration is usually "cross hatched, and the decorative elements may be embellished with ticks, hatched lines, or engraved segments" (Early 1993:90).

Three whole vessels from the Hardman site collection were reported as Friendship Engraved var. Freeman. Early also reported over 200 vessels from the ARAS photo files for this type, "and virtually all of them came from sites in the middle Ouachita River valley between Arkadelphia and Malvern" (Early 1993:90).

Five whole vessels from the Ferguson site are of the Friendship Engraved type. Four are carinated bowls and one is a conjoined triple carinated bowl (Acc. \#: 72-22-1772-28.30.32). That vessel, along with three others (Acc. \#s: 72-22-1772-17, 72-22-1772-19, 72-22-1772-26) are from Burial 21 (Mound B, Feature $8)$. Another bowl resembling this type was found in Burial 5 (Mound B Feature 32). Ferguson Vessel 34 


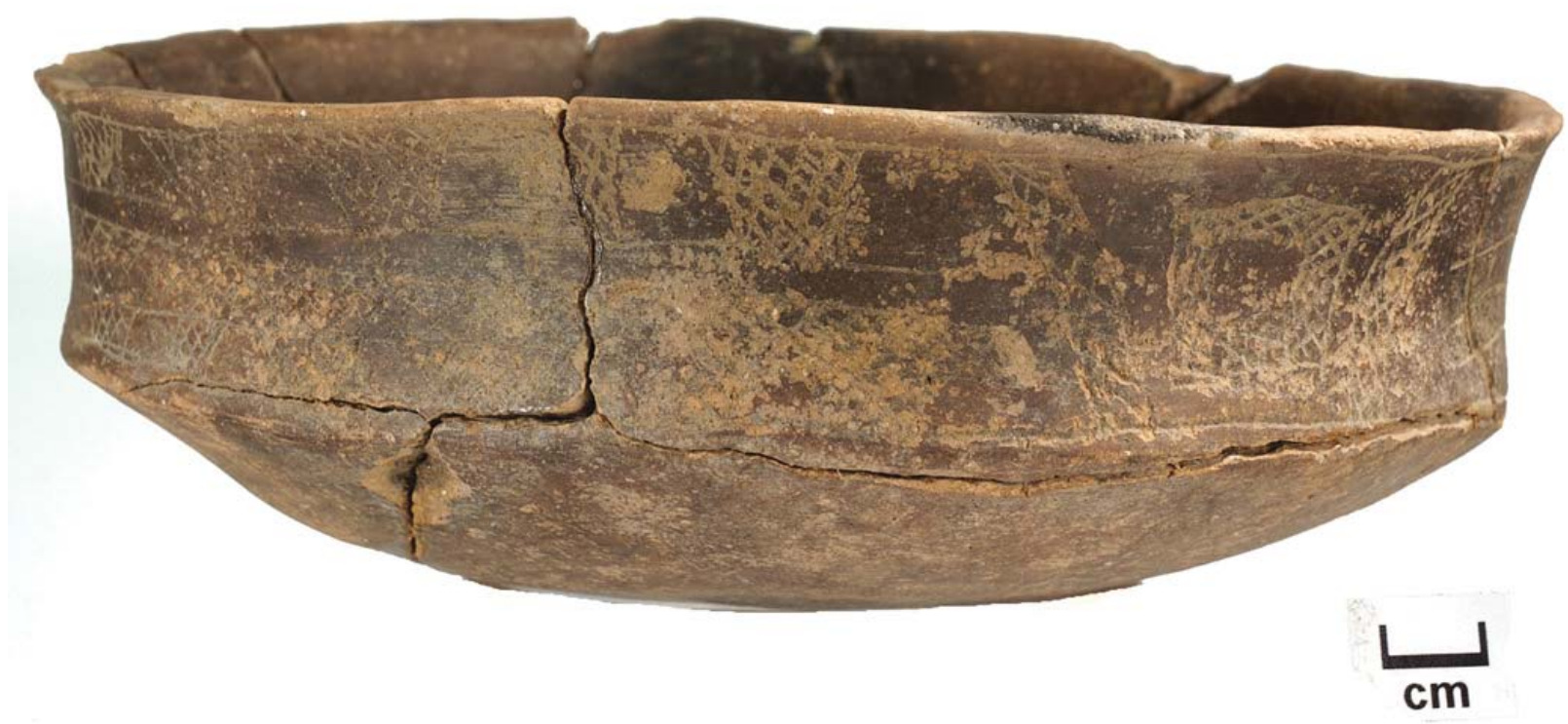

Figure 6. Friendship Engraved Bowl (Vessel 32, Acc. \#: 72-22-1772-26).

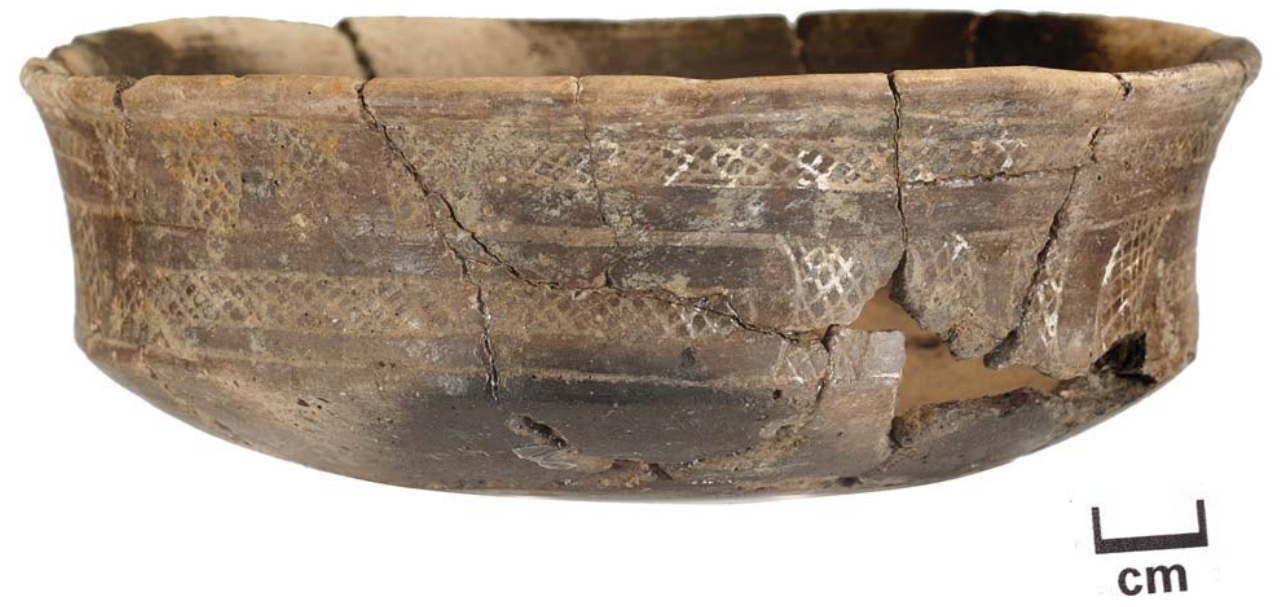

Figure 7. Friendship Engraved Bowl (Vessel 29, Acc. \#: 72-22-1772-19).

(Acc. \#: 72-22-1772-28.30.32) is a triple conjoined bowl that originated in Burial 21 (Mound B, Feature 8) and matches the Friendship Engraved var. Freeman type (Figure 8).

One vessel similar to Friendship Engraved var. Antoine was found at Ferguson in Burial 21 (Mound $\mathrm{B}$, Feature 8). Schambach notes that a 4-cogged rim carinated bowl (Acc. \#: 2003-675-48) from the A-7 House at the Tom Jones site (3HE40) is a virtual twin to the Ferguson site vessel. The Tom Jones site bowl is from a well dated floor context 2-Sigma cal A.D. 1280-1425 (Frank Schambach, personal communication 2010). The Ferguson Vessel 27 (Acc. \#: 72-22-1772-17) bowl and the Tom Jones bowl both have four decorated panels with scrolls cross-hatching and spurred lines (Figures 9 and 10). The Ferguson site sample is grit tempered.

\section{Glassell Engraved}

Glassell Engraved is a Caddo fineware pottery type that has little to no visible temper, a fine and compact texture, and has a mahogany brown to black color shading into dark gray-browns, although occasionally buff or reddish-brown. The cores are darker than the surfaces and are mottled (Suhm and Jelks 1962:53). 


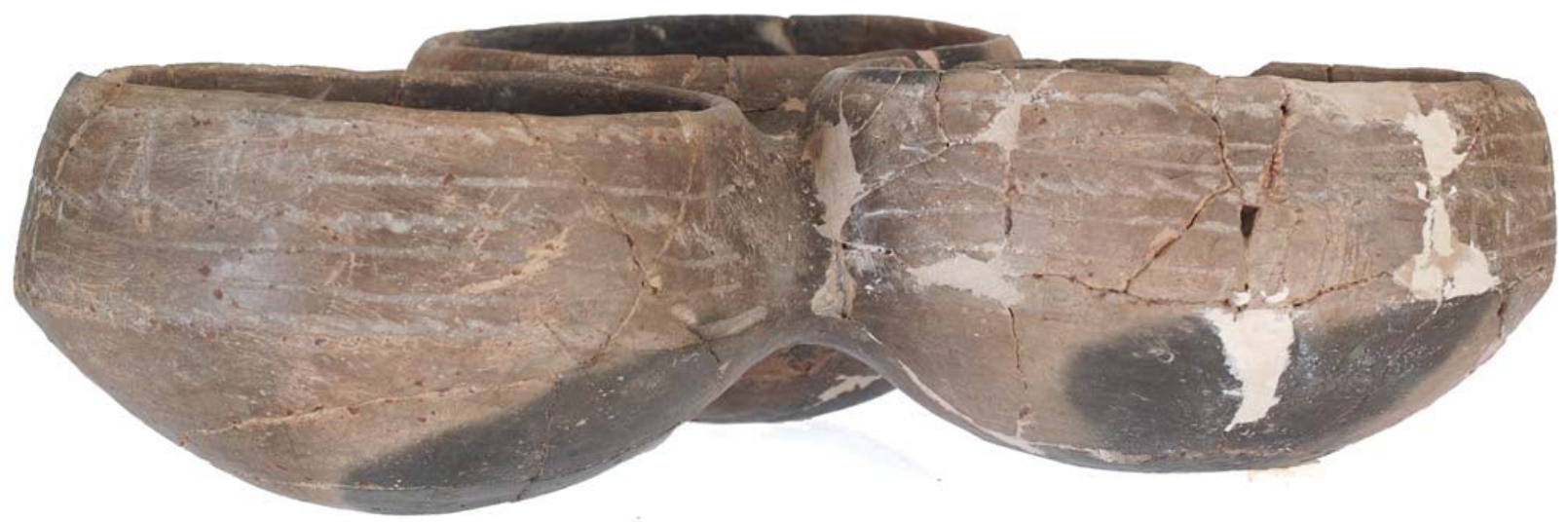

Figure 8. Friendship Engraved triple conjoined bowl (Vessel 34, Acc. \#: 72-22-1772-28.30.32)

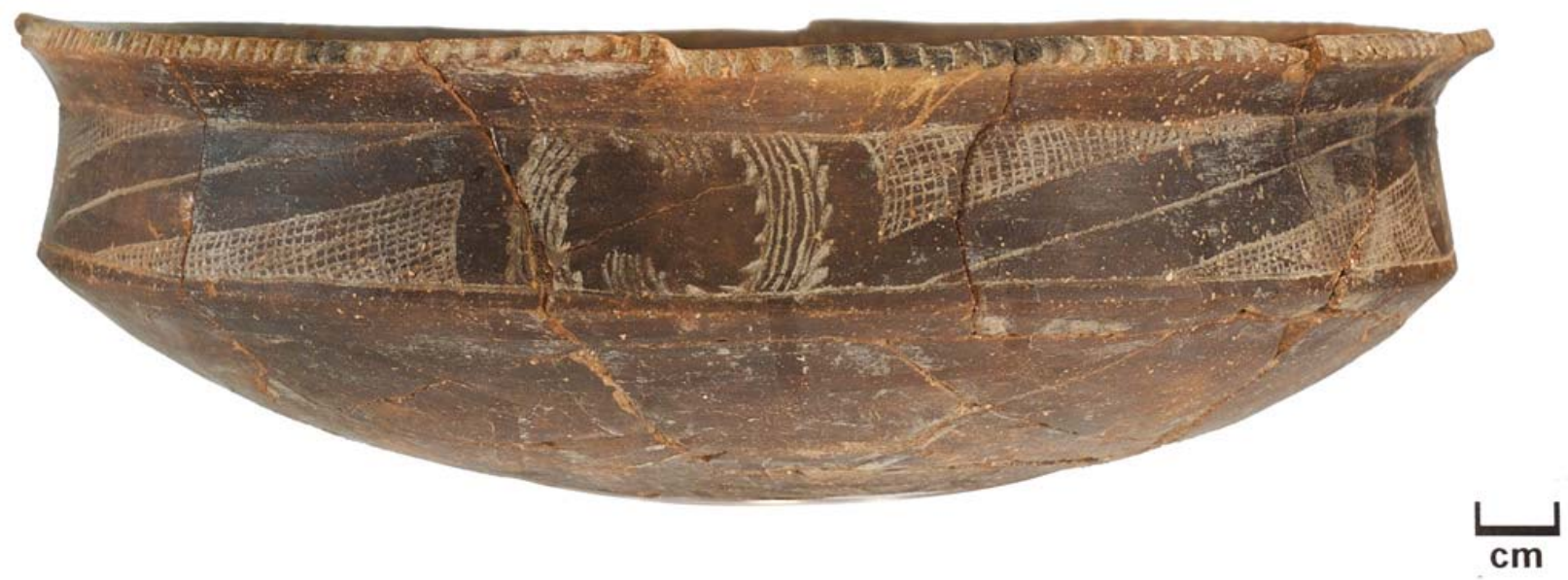

Figure 9. Side view: Friendship Engraved var. Antoine (Vessel 27, Acc. \#: 72-22-1772-17).

Vessel surfaces are smoothed to well-polished. Bowls of this type are finished the same on the exterior and interior. Bottles are polished on the outside, but are not smoothed on the inside.

Known vessel forms of the Glassell Engraved type includes carinated bowls and bottles. The bowls have slightly convex or slanted inward rims. Bottles have globular bodies and spouts that are usually "long and swelling near [the] middle, but spouts may also be larger at the top than at bottom" (Suhm and Jelks 1962:53). Wall thickness varies between 3-5 mm. The lip is "usually thickened with a strip of clay attached to outer edge, which sometimes splits off; otherwise, thin, wedge-like" (Suhm and Jelks 1962:53). The base is convex on bowls, and slightly convex to flat on bottles.

Glassell Engraved vessels are engraved with decorations including rectilinear patterns, ticked or spurred lines running "horizontally through center of blank space and either ends against an arc placed vertically, or makes a step up or down and runs through another such blank space" (Suhm and Jelks 1962:53). Arched lines are placed back-to-back vertically providing "dividing elements" between panels, and between the four major units of the design. Bottles possess various "combinations of curved lines and circles in which principal diagnostic feature is common use of very narrow 'ladders,' or parallel lines with closely-spaced cross-lines" (Suhm and Jelks 1962:53). Additionally, narrow hatched or cross-hatched bands are used on Glassell Engraved designs, along with red pigment.

Two carinated bowls of the Glassell Engraved type were found within Ferguson site Burial 1-4 and 21 group graves. Vessel 6 (Acc. \#: 72-22-101-07) was 


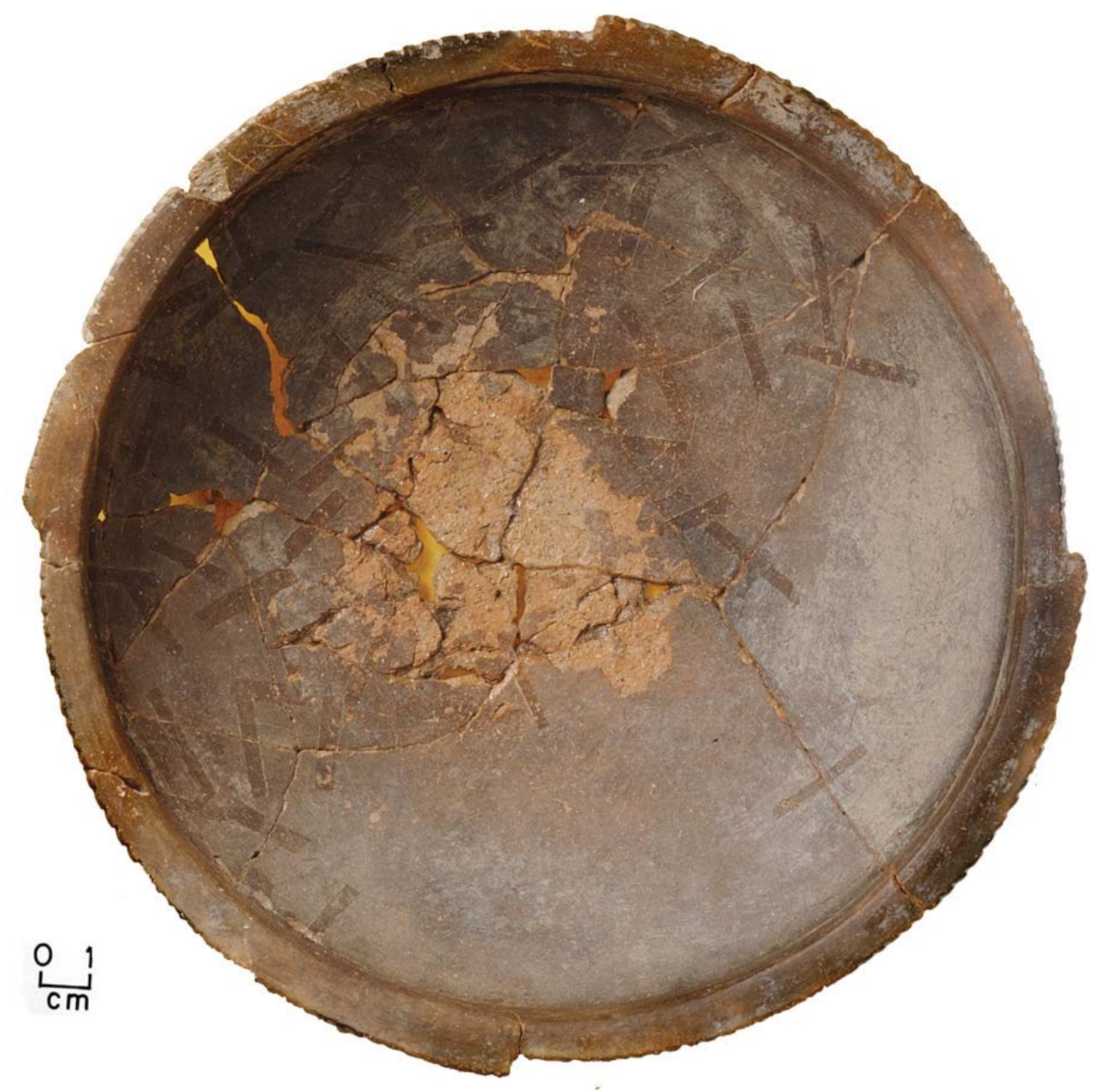

Figure 10. Top view: Friendship Engraved var. Antoine (Vessel 27, Acc. \#: 72-22-1772-17).

a carinated bowl excavated with the Burial 1-4 group (Mound B, Feature 2) (Figure 11). Pigments may have been present within the engraved lines of this sample at one time, but are no longer visible. The bowl has some dark stains around rim and one side of exterior and had some visible grit and bone temper.

\section{Haley Complicated Incised}

Haley Complicated Incised vessels have a clay-grit temper, usually a coarse somewhat crumbly texture, though "occasionally finer and firmer" (Suhm and Jelks
1962:59). The range of color for this type includes from light to dark shades of brown and gray-brown with cores darker than surfaces. Haley Complicated Incised vessels consist "almost entirely of small jars, about $10-25 \mathrm{~cm}$. high" (Suhm and Jelks 1962:59). Some have outflaring rims, while others have high and cylindrical rims. Two wide strap handles are found on the latter rim form. The rims may be "raised into four prominent peaks... either with or without strap handles" (Suhm and Jelks 1962:59).

Based on paste, Haley Complicated Incised is considered a Caddo 'course' or utilitarian ware. Despite 


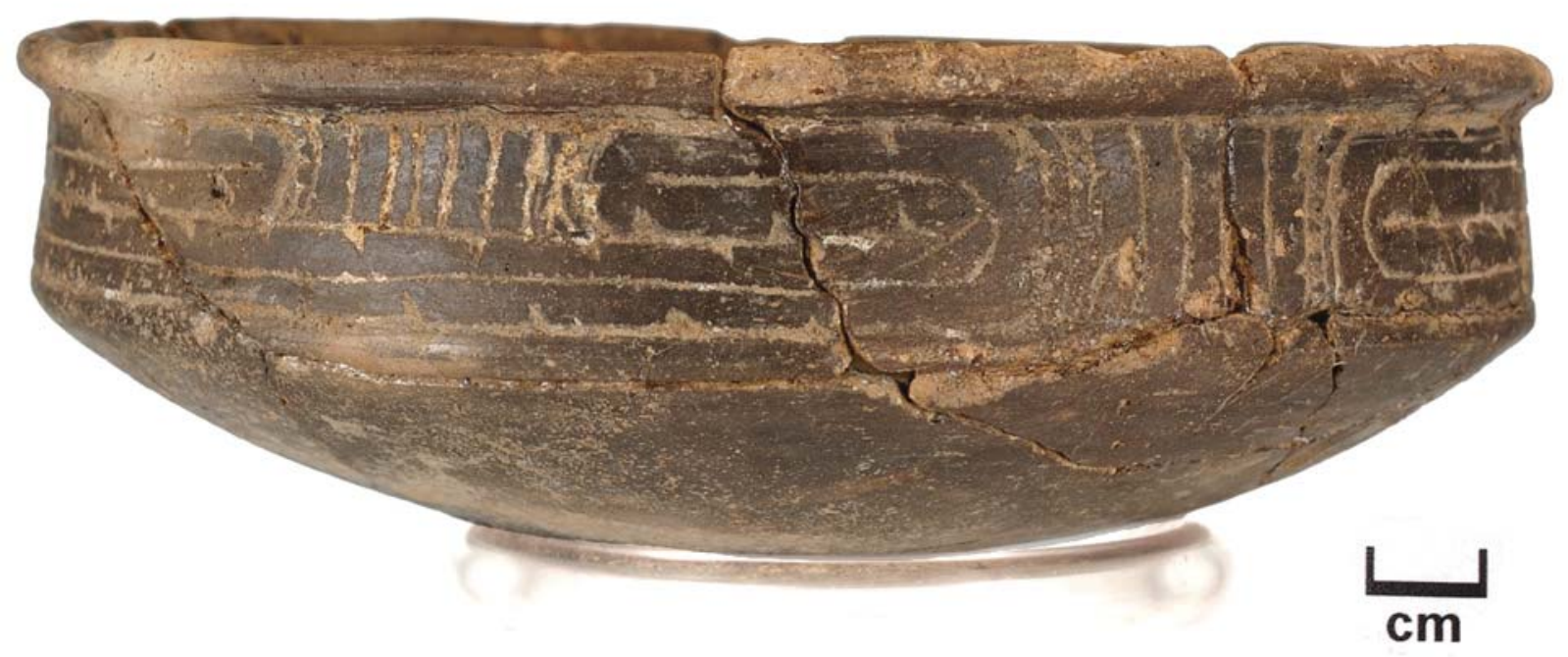

Figure 11. Glassell Engraved (Vessel 6, Acc. \#: 72-22-101-07).

this association, the decorations on these vessels are very baroque with various appliqued, incised, and punctated elements. The designs include: "Concentric circles, scrolls, and parallel diagonal lines set in a wide variety of arrangements. Small areas flanking main design units may be filled with stick punctates or parallel lines, or both" (Suhm and Jelks 1962:59). Also found are "sets of fine diagonal or spiral lines may be alternated with single rows of fillets running vertically, diagonally... [with] the fillets usually being notched or punctated along the top" (Suhm and Jelks 1962:59). Strap handles found on these vessels have the same range of decorations as the bodies. Jars with high rims may have rows of horizontal punctates midway, which rise into punctate-filled triangles below the four rim peaks. The lips of these vessels are often notched along the outer edge.

Both of the large group Caddo shaft graves in Mound B, Burial 21 (Mound B, Feature 8) and Burial 1-4 (Mound B, Feature 2) had a Haley Complicated Incised jar among the grave goods. They are Vessel 7 (Acc. \#: 72-22-101-8) and Vessel 18 (Acc. \#: 7222-1772-2) (Figures 12a and 12b). Both are barrelshaped jars with an outsloping rim, slightly everted lip, triangular handles, and a circular and convex base. The jars have a clay and bone temper, the paste is soft, fine, and compact, and the whole body have fire-mottled exteriors.

\section{Haley Engraved}

Haley Engraved is a Caddo fineware type that was described in detail by Suhm et al. (1954:274) as having a paste composed of fine clay-grit, with either a small amount of sand, or none. The texture is fine and compact. The color of Haley Engraved vessels include shades of brown and gray-brown from medium to nearly black, with cores as dark as, or darker than, the surface. The surface finishes are well smoothed to highly polished with bottles unsmoothed inside.

Haley Engraved vessel forms are predominately bottles. The bodies are typically small and necks are cylindrical or slightly tapered toward the mouth. Suhm and Jelks (1962: 62, Plate 31) illustrated one example of a Haley vessel with a small body and large cylindrical neck and two vertically-perforated lugs on the rim. Also, the type includes large, high compound bowls, with an inverted shoulder area and outflaring rim, with two broad handles. Wall thickness range for 3-5 $\mathrm{mm}$. Lips are rounded or flat and flush with the rim. The bases of the vessels are flat to slightly convex, and have the same thickness as the side wall.

In terms of decoration, Haley Engraved vessels are engraved with "gracefully arranged scrolls, doubled-back meanders, or vertical panels, consisting of very fine lines in parallel sets, or more open work with individual lines and tightly packed sets which appear almost like excising. Slanting ticks and spurs appear 

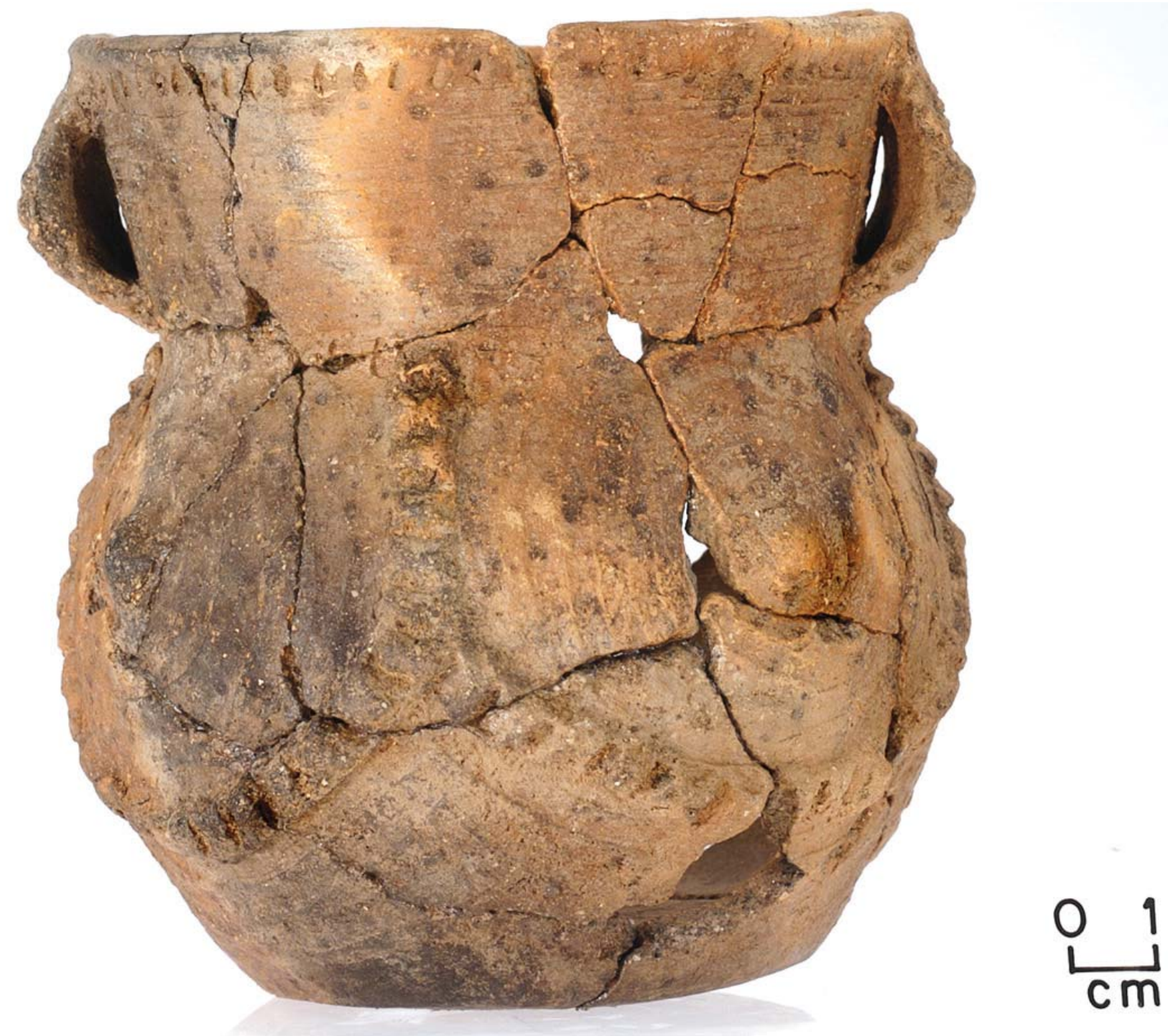

Figure 12a. Haley Complicated Incised (Vessel 7, Acc. \#: 72-22-101-8).

commonly in opposing pars (on different lines, running close together), either as the principal element in any of several ways; ticks also occur along single lines as bordering elements. Design units repeated two, three, or four times. Red and white pigments occur in lines" (Suhm and Jelks 1962:61).

Haley Engraved, var. Caruse. Haley Engraved var. Caruse is an "engraved type characterized by multiplelined curvilinear and rectilinear units combined in a complex layout" with "borders usually lined with ticks" (Brown 1996:377). The variety Caruse was distinguished by Schambach to include bottle shapes with square shoulders and vertical panels with predominantly rectilinear designs. At the Spiro site, Haley Engraved var. Caruse samples included one narrow-mouthed bottle in the card sample, the sherds of two narrow-mouthed and one wide mouth bottle, and one bowl (Brown 1996:377).

Eight square shouldered bottles from the elite Caddo shaft graves Burial 1-4, 5, and Burial 21 at Ferguson are identified as Haley Engraved var. Caruse. Similar vessels have also been noted from the Mineral Springs site (3HO1) Burial 9 (see Bohannon 1973:23 and Figure 10-q). Haley Engraved var. Caruse was also recovered from the Spiro site (34LF40) Burials 7 and 62, as well as from the Craig Mound general collection (Brown 1996:378). 


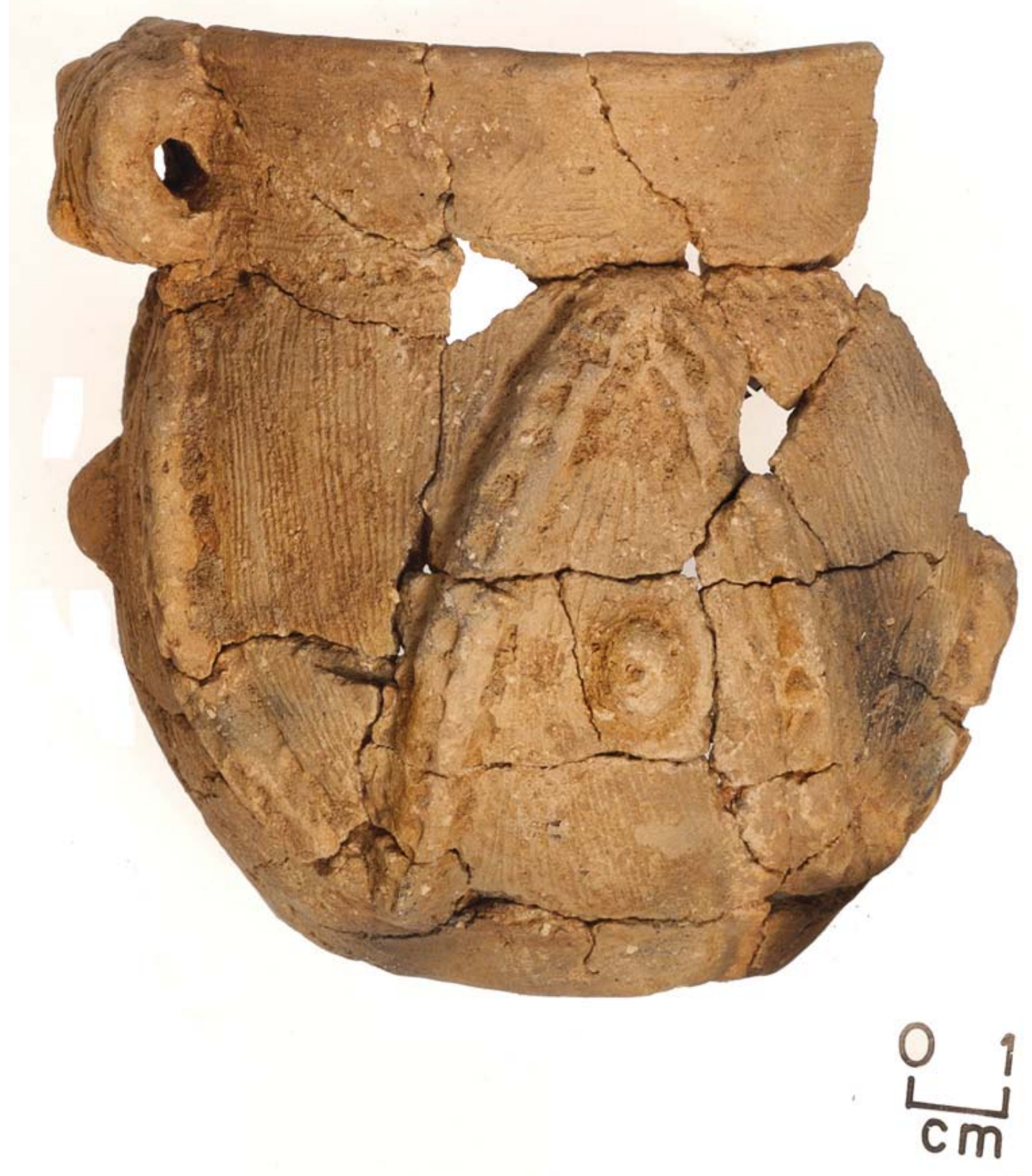

Figure 12b. Haley Complicated Incised (Vessel 18, Acc. \#: 72-22-1772-2).

Ferguson Vessel 1 (Acc. \#: 72-22-101-01) is associated with Burials 1-4 (Mound B, Feature 2). This square shouldered cylindrical bottle has a vertical slightly insloping rim, a rolled lip, slightly insloping neck, and a square and flat base (Figure 13c). This bottle is one of five Haley Engraved var Caruse (Brown 1996) bottles from the Mound B, Feature 2 burial group. It is very similar in vessel form but distinct with engraved line designs including: 1) multiple spurred line disc patterns, 2) arc spurred line panels, 3) cross-hatched 


\begin{tabular}{c|cccccc} 
& $\begin{array}{c}\text { Vessel } \\
\text { Number }\end{array}$ & $\begin{array}{c}\text { Accession } \\
\text { Number }\end{array}$ & Collection Area & Associated Burial(s) & Type & Variety \\
\hline a & 04 & $72-22-101-4$ & Mound B, Feature 2 & Burials 1, 2, 3, 4 & Haley Engraved & Caruse \\
b & 11 & $72-22-101-12$ & Mound B, Feature 2 & Burials 1, 2, 3, 4 & Haley Engraved & Caruse \\
c & 01 & $72-22-101-1$ & Mound B, Feature 2 & Burials 1, 2, 3, 4 & Haley Engraved & Caruse \\
d & 02 & $72-22-101-2$ & Mound B, Feature 2 & Burials 1, 2, 3, 4 & Haley Engraved & Caruse \\
e & 03 & $72-22-101-3$ & Mound B, Feature 2 & Burials 1, 2, 3, 4 & Haley Engraved & Caruse
\end{tabular}

Table 4. Haley Engraved bottles from the Ferguson site.

zones, 4) oblique lined arc-lined zones, 5) rectangular partial scrolls, and 6) partial vertical stepped scrolls. The bottle has a grit and bone temper and a fine and compact paste. The entire body has engraved lines filled with red pigment.

Vessel 2 (Acc. \#: 72-22-101-02) is associated with Burials 1-4 (Mound B, Feature 2). This square shouldered cylindrical bottle has a vertical slightly insloping rim, a rolled lip, slightly insloping neck, and a square and flat base (Figure 13d). The bottle is very similar in vessel form but distinct similar in vessel form the other Haley bottles form this grave with engraved line designs including: 1) oblique lined arc-lined zones, 2) convex arced outlines within a central element, 3 ) arc spaced spurred line panels, and 4) spurred lines adjacent to central element spacers. The exterior appears thermally altered and there is an unknown dark residue on one side of the neck. The temper consists of grit and bone and the paste is fine and compact. The entire body is engraved with engraved lines filed with red or white pigment.

Vessel 3 (Acc. \#: 72-22-101-03) is associated with Burials 1-4 (Mound B, Feature 2). This square shouldered cylindrical bottle has a vertical to vertical slightly insloping rim, a flat lip, vertical to slightly insloping neck, and a square and flat base (Figure 13d). The bottle is very similar in vessel form the other Haley bottles form this grave but distinct with engraved line designs including: 1) crosshatched zones, 2) spurred lines adjacent to central elements, arc spaced spurred line panels, 3) arc spaced spurred line panels, 4) multiple spurred line disc patterns (with annular lines between discs), 5) convex arced central elements, 6) rectilinear partial scrolls, and 7) partial vertical stepped scrolls. Entire body has engraved lines with red pigment. The temper is composed of grit and bone and the paste is fine and compact.

Vessel 4 (Acc. \#: 72-22-101-04) is associated with Burials 1-4 (Mound B, Feature 2). This square shouldered cylindrical bottle has a vertical to vertical slightly insloping rim, a flat lip, vertical to slightly insloping neck, and a square and flat base (Figure 13a). The bottle is very similar in vessel form but distinct in vessel design from the other Haley bottles form this grave with engraved line designs including: 1) multiple spurred lines outlining scroll panels, 2) spurred ticked lines between central design elements, 3) rectangular and disced spacer panels, and 4) and vertical as well as horizontal annular lines. The top two-thirds of the body has engraved designs filled with red pigment, which are separated into seven design panels. Three annular lines wrap the threshold between the body and neck. There is obvious wear around diameter of neck of an unknown cause. The temper includes grit with some bone and the paste is fine and compact.

Vessel 11 (Acc. \#: 72-22-101-12) is associated with Burials 1-4 (Mound B, Feature 2). This square shouldered cylindrical bottle has vertical slightly insloping rim, a slightly rolled lip, slightly insloping neck, and a square and flat base (Figure 13b). The bottle is very similar in vessel form but distinct in vessel design from the other Haley bottles from this grave with engraved line designs including: 1) convex arc elements (with both filled and/or unfilled lines), 2) annular rows of triangles, and 3) disced areas. The entire body is engraved with engraved lines filed with red or light gray pigment. The vessel temper is bone and the paste is fine and compact and this bottle was found crushed on its side.

Vessel 15 (Acc. \#: 72-22-341-03) is associated with Burial 5 (Mound B, Feature 32) an adult female 

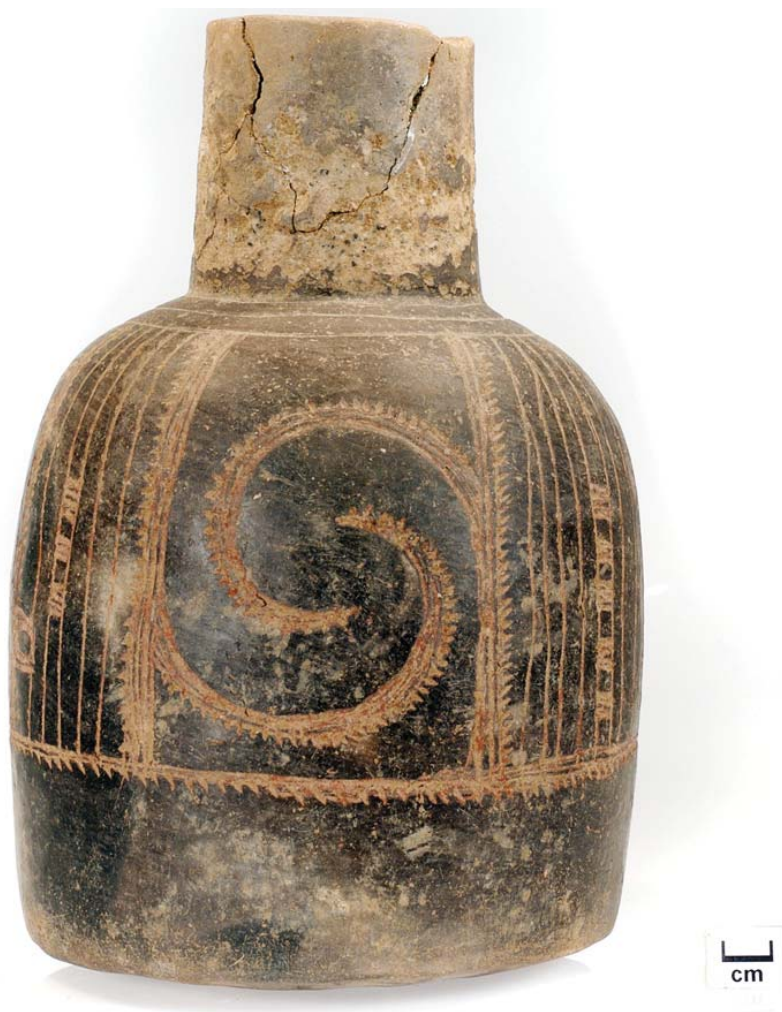

Figure 13a. Haley Engraved var. Caruse bottle from Burial 1-4, (Mound B, Feature 2) (Vessel 4, Acc. \#: 72-22-101-4).

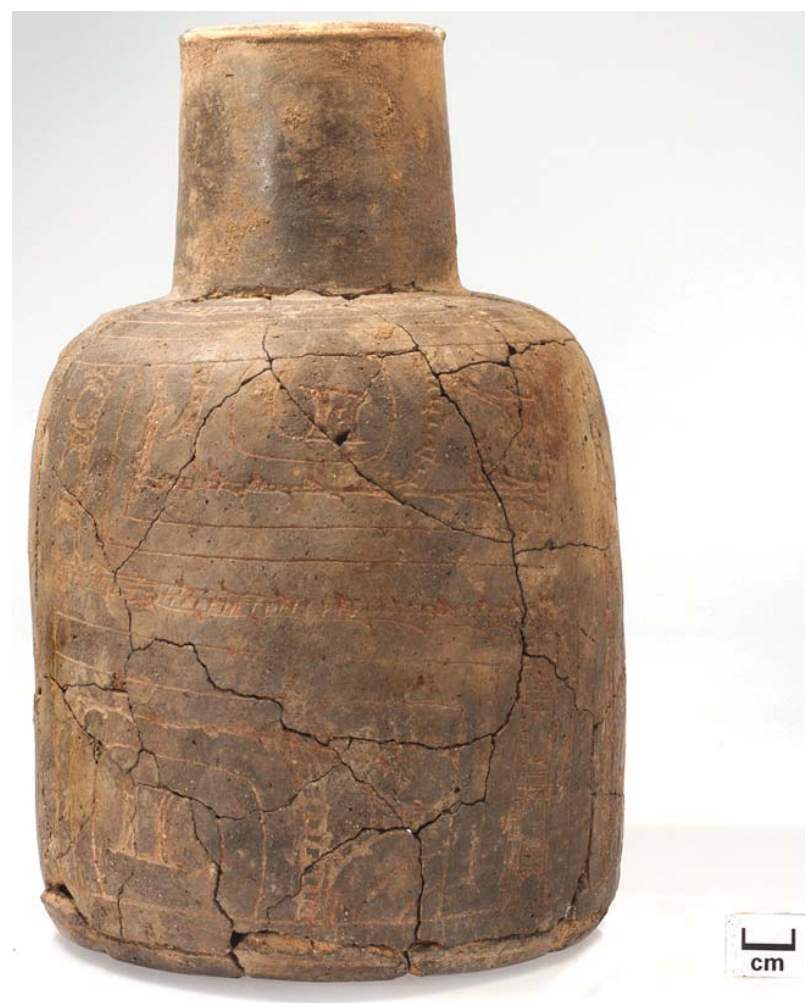

Figure 13c. Haley Engraved var. Caruse bottle from Burial 1-4, (Mound B, Feature 2) (Vessel 1, Acc. \#: 72-22-101-1).

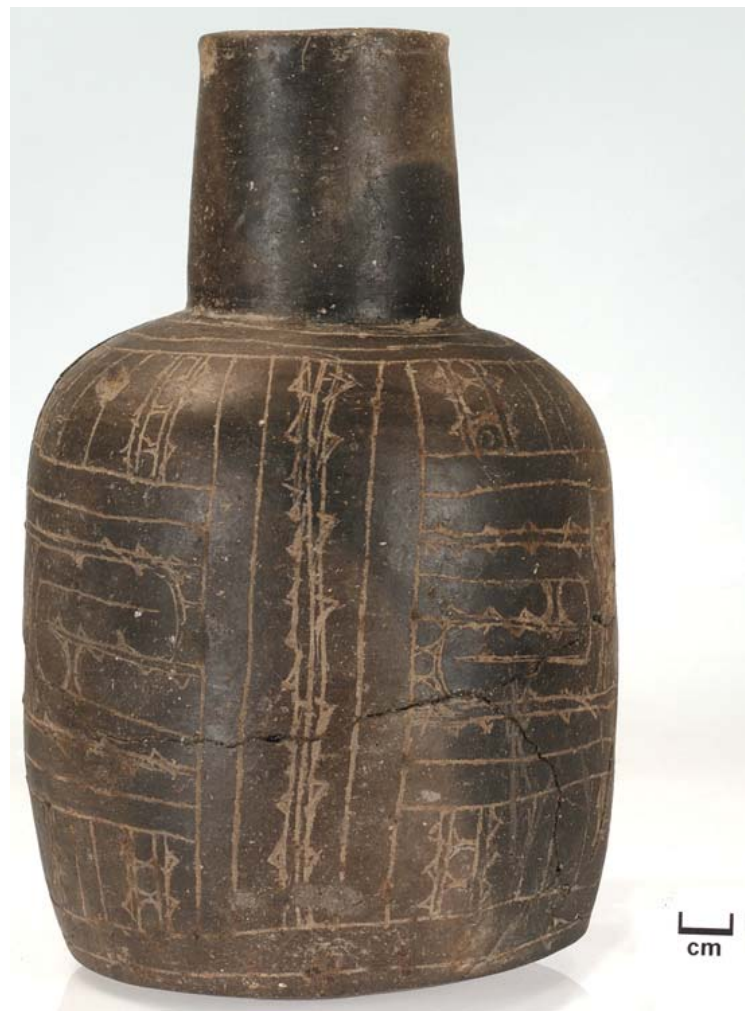

Figure 13b. Haley Engraved var. Caruse bottle from Burial 1-4, (Mound B, Feature 2) (Vessel 11, Acc. \#: 72-22-101-12).

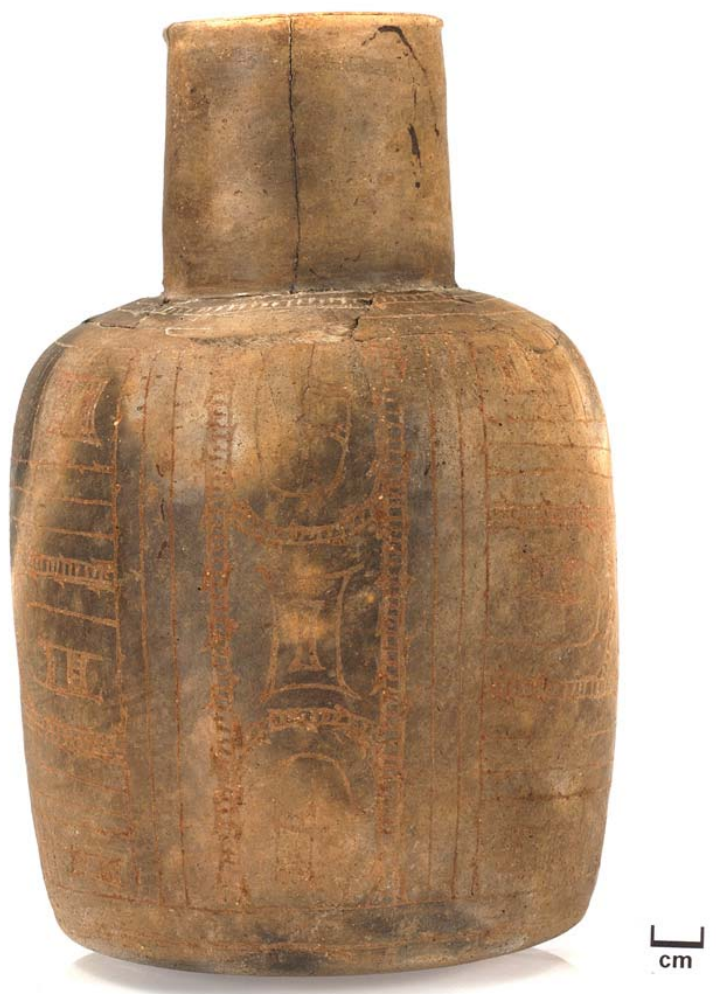

Figure 13d. Haley Engraved var. Caruse bottle from Burial 1-4, (Mound B, Feature 2) (Vessel 2, Acc. \#: 72-22-101-2). 


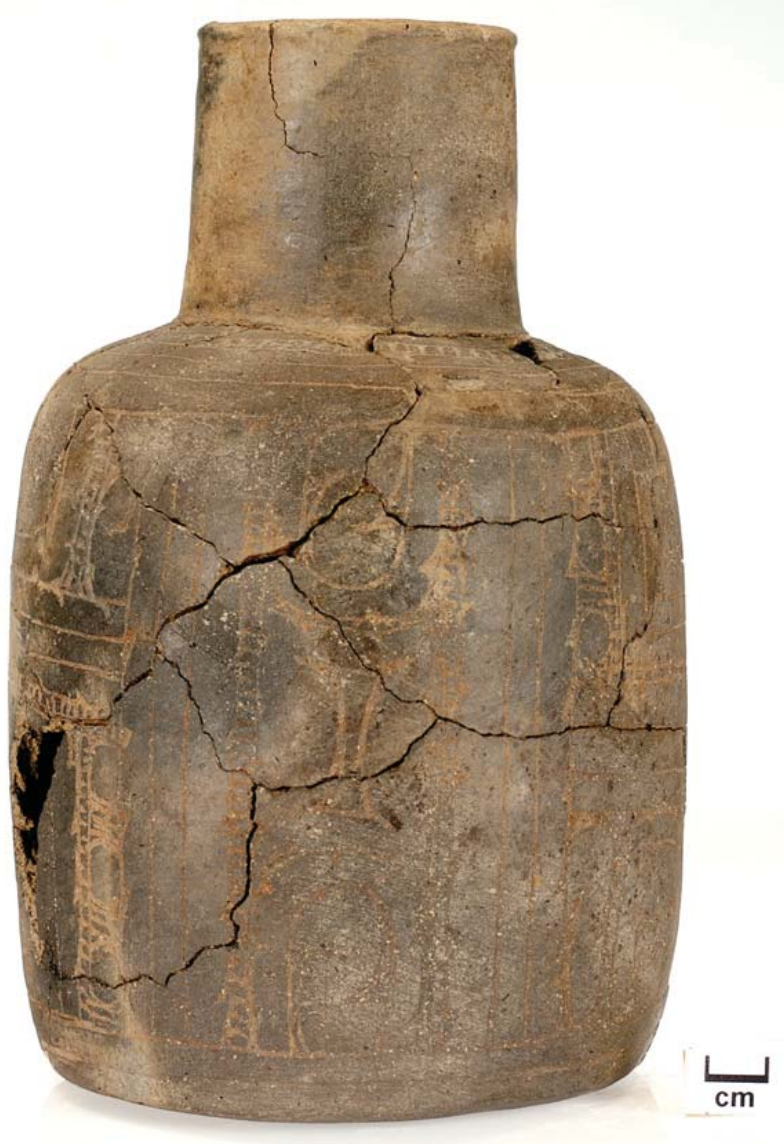

Figure 13e. Haley Engraved var. Caruse bottle from Burial 1-4, (Mound B, Feature 2) (Vessel 3, Acc. \#: 72-22-101-3).

burial within Mound B. This tear dropped bottle has a vertical slightly insloping rim, slighlty rolled lip, an insloping slightly curved neck, and a square and flat base (Figure 14e). The body is engraved with geometric lines and cross-hatching, separated into four horizontal patterned design fields. Three engraved lines run parallel around the rim, just below the lip. There is some visual evidence of red pigment within the engraved lines. The temper is composed of grit and bone and the paste is hard and compact.

Vessel 26 (Acc. \#: 72-22-1772-13) is associated with Burial 21 (Mound B, Feature 8), a central shaft grave intruding Mound B. This cylindrical tear-dropped bottle has a slightly everted lip, an outsloping-slightly incurved neck, and a square and flat base (Figure 14d). Red pigment is visible inside the engraved lines on the vessel body. The paste is compact and the temper includes grit and possible crushed mica and hematite. The vessel has an ink-like residue on and below the neck. This Haley Engraved var. Caruse bottle is similar in form and design to Vessel 30 (Acc. \#: 72-22-177220). The stepped Davis Rectangle designs on the bodies look like mirror-opposites of each other. Vessel 26 has red pigment in the engraved lines while Vessel 30 has light grey/white pigment in the lines.

Vessel 30 (Acc \#: 72-22-1772-20) is associated with Burial 21 (Mound B, Feature 8), a central shaft grave intruding Mound B. This cylindrical-tear drop shaped bottle has a slightly everted lip, outslopingslighlty curved neck, and a square and flat base (Figure 14c). The paste is compact and the temper included grit and bone. The engraved lines throughout are separated into four rectilinear design fields with light pigment filling the engraved lines. Unknown brown encrustations are visible on the neck.

Haley Engraved var. Adams. Haley Engraved var. Adams was constructed as a tentative type by Bohannon (1973:45) based on two vessels recovered from the Mineral Springs site (Table 5). Webb (1959:187) previously reasoned that this variety of bottle was "transitional between Haley Engraved and Belcher Engraved" with the "shape and concentric circle motif [being] typical of Belcher Engraved, but [lacking] the punctates between the lines diagnostic of that type" (Bohannon 1973:45). These vessels include globular or oblate bottles with disc bases and short cylindrical necks. The decoration includes two lines encircling the top of the body, with the body being "divided into two panels by excised spurred band or paired engraved lines" (Bohannon 1973:45). Each of the panels contains a series of concentric circles with plain, ticked, or spurred lines. Red pigment was found in the engraved lines of the Mineral Springs bottles.

Ferguson Vessel 23 (Acc. \#: 72-22-1772-08) originated in Burial 21 (Mound B, Feature 8). This globular bottle has a slightly everted lip, slightly insloping neck, and a circular and flat base (Figure 14a). The temper includes clay, grit, bone, and hematite, while the paste is hard and compact. The engraved lines include concentric circles and 'sunbursts' on two sides, with 'ticked lines' filling the concentric circles. White pigment was found in its lines, in contrast with the red pigment found in the Haley Engraved var. Adams vessels from the Mineral Springs site. 


\begin{tabular}{c|cclllc} 
& $\begin{array}{c}\text { Vessel } \\
\text { Number }\end{array}$ & $\begin{array}{c}\text { Accession } \\
\text { Number }\end{array}$ & Collection Area & $\begin{array}{l}\text { Associated } \\
\text { Burial(s) }\end{array}$ & Type & Variety \\
\hline a & 23 & $72-22-1772-8$ & Mound B, Feature 8 & Burial 21 & Haley Engraved & Adams \\
b & 43 & $72-22-1513-9$ & Plot 3, Feature 8 & Burial 11 & Haley Engraved & - \\
c & 30 & $72-22-1772-20$ & Mound B, Feature 8 & Burial 21 & Haley Engraved & Caruse \\
d & 26 & $72-22-1772-13$ & Mound B, Feature 8 & Burial 21 & Haley Engraved & Caruse \\
e & 15 & $72-22-341-3$ & Mound B, Feature 32 & Burial 5 & Haley Engraved & Caruse
\end{tabular}

Table 5. Haley Engraved bottles from the Ferguson site

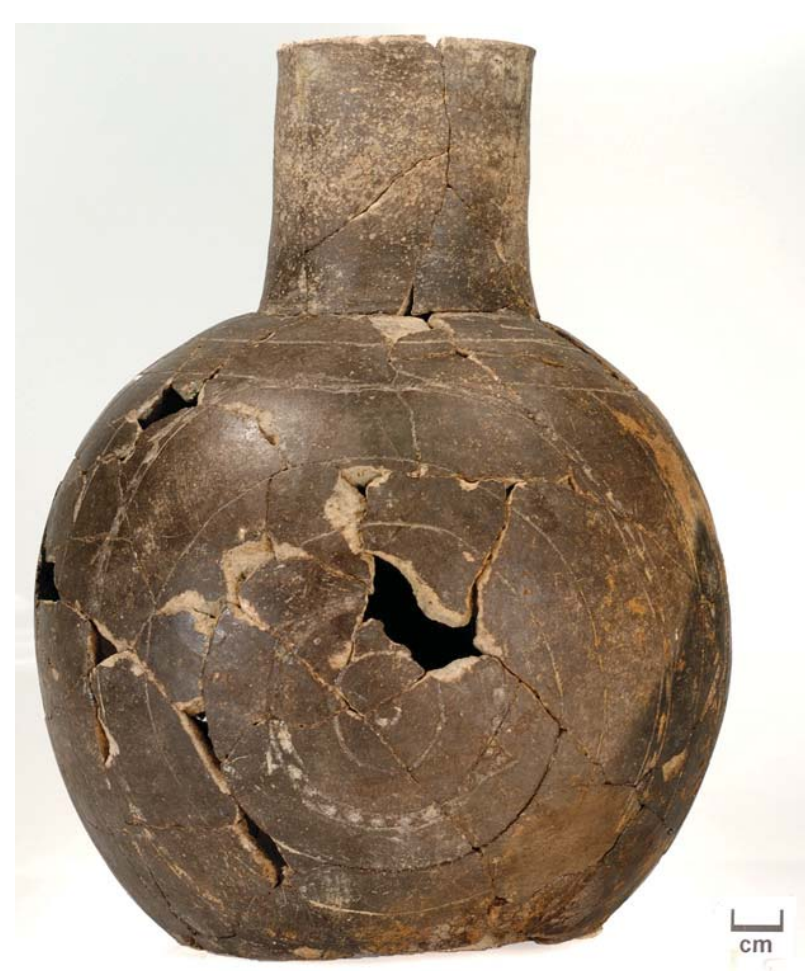

Figure 14a. Haley Engraved var. Adams bottle from Burial 21, (Mound B, Feature 8) (Vessel 23, Acc. \#: 72-22-1772-8).

\section{Hempstead Engraved}

Hempstead Engraved vessels are a Caddo ceramic fineware that have a fine and compact paste "somewhat harder than most Caddoan pottery" including a fine clay-grit, shell, or trace of sand in the temper (Suhm and Jelks 1962:69). These vessels have a light yellowishbrown to dark brown and gray color. The surfaces are fair to polished.

Hempstead Engraved vessel forms include small and large carinated bowls, hemispherical bowls, and bottles. Wall thicknesses typically range from

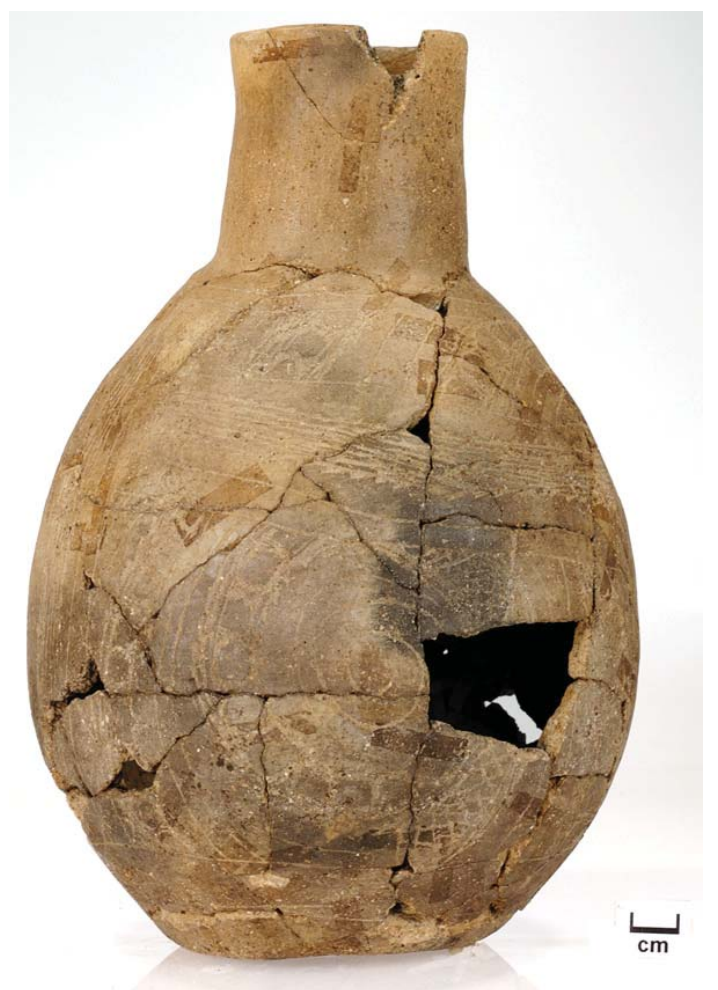

Figure 14b. Haley Engraved bottle from Burial 11, (Plot 3, Feature 8) (Vessel 43, Acc. \#: 72-22-1513-9).

3-5 $\mathrm{mm}$. The lips are convex on bowls and tend to be more flattened on bottles. The engraved designs principally include "pairs of hatched or cross-hatched triangles placed around rim of bowls... and around body on bottles" (Suhm and Jelks 1962:69). They include one to three horizontal borderlines above the triangles and at least one below. Hempstead Engraved vessels may also include right triangles or pendant triangles. Red pigment is typically placed in engraved lines.

Three Hempstead Engraved bottles including Vessel 31 (Acc. \#: 72-22-1772-25), Vessel 35 (Acc. \#: 72-22-1772-29), and Vessel 37 (Acc. \#: 72-23-1772-34) 


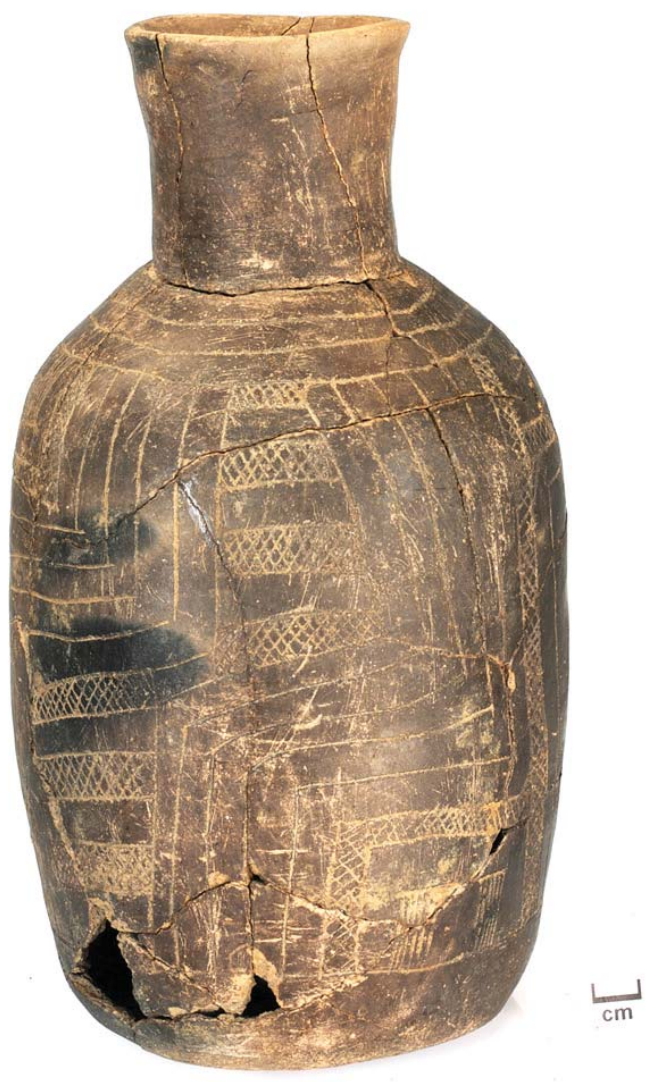

Figure 14c. Haley Engraved var. Caruse bottle from Burial 21, (Mound B, Feature 8) (Vessel 30, Acc. \#: 72-22-1772-20).

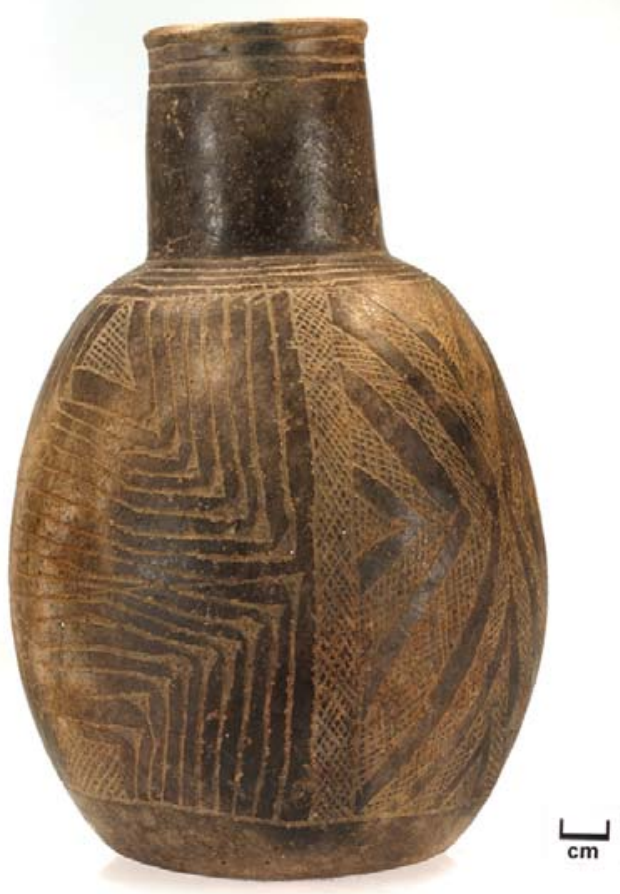

Figure 14e. Haley Engraved var. Caruse bottle from Burial 5, (Mound B, Feature 32) (Vessel 15, Acc. \#: 72-22-341-3).

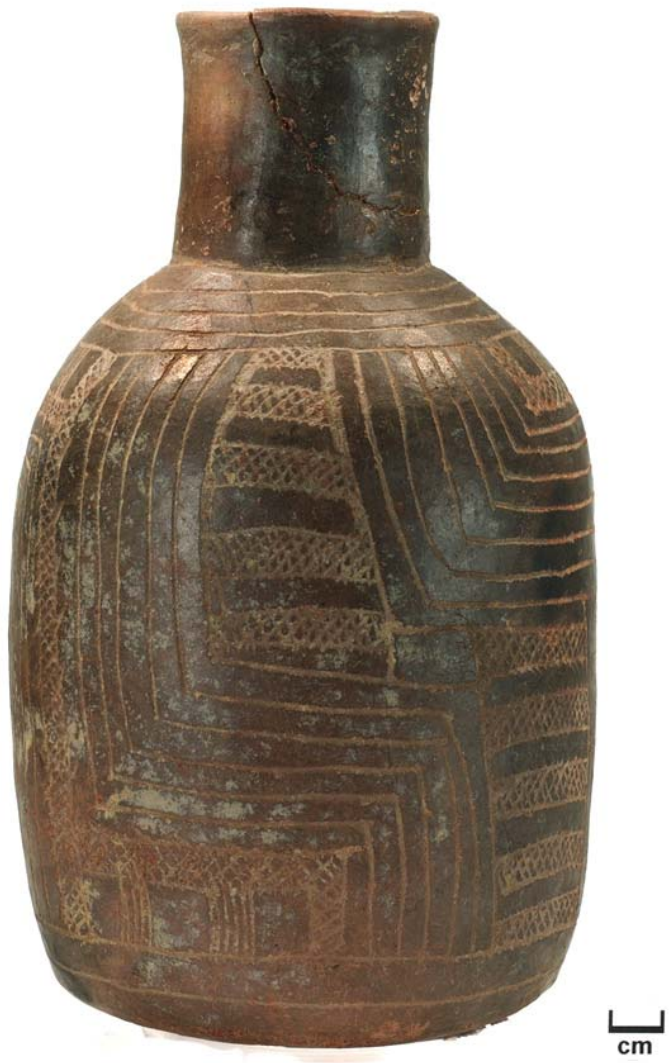

Figure 14d. Haley Engraved var. Caruse bottle from Burial 21, (Mound B, Feature 8) (Vessel 26, Acc. \#: 72-22-1772-13).

were recovered at the Ferguson site were from Burial 21 (Mound B, Feature 8). Vessel 35 (Acc. \#: 72-22-1772-29) is a globular bottle with a vertical slightly outsloping rim, a slightly rolled lip, an outsloping slightly incurved neck, and a circular and convex base (Figure 15). This vessel has clay, grit, and bone temper. Parallel engraved lines are etched to the lip, and diagonal tics run along bottom, with engraved lines spanning the circumference of the neck. 'Sun-burst'-like patterns are on the vessel body, made of composed of four concentric circles surrounded by triangles. Also, opposing triangles at the top and bottoms are filled with cross-hatched lines and annular engraved lines around the top of body.

\section{Karnack Brushed Incised}

Karnack Brushed-Incised is a Caddo ceramic utilitarian ware type having a fine to coarse texture and a clay-grit temper with occasional pulverized bone temper. These vessels have surface colors that range from cream to shades of gray and brown to nearly black (Suhm and 


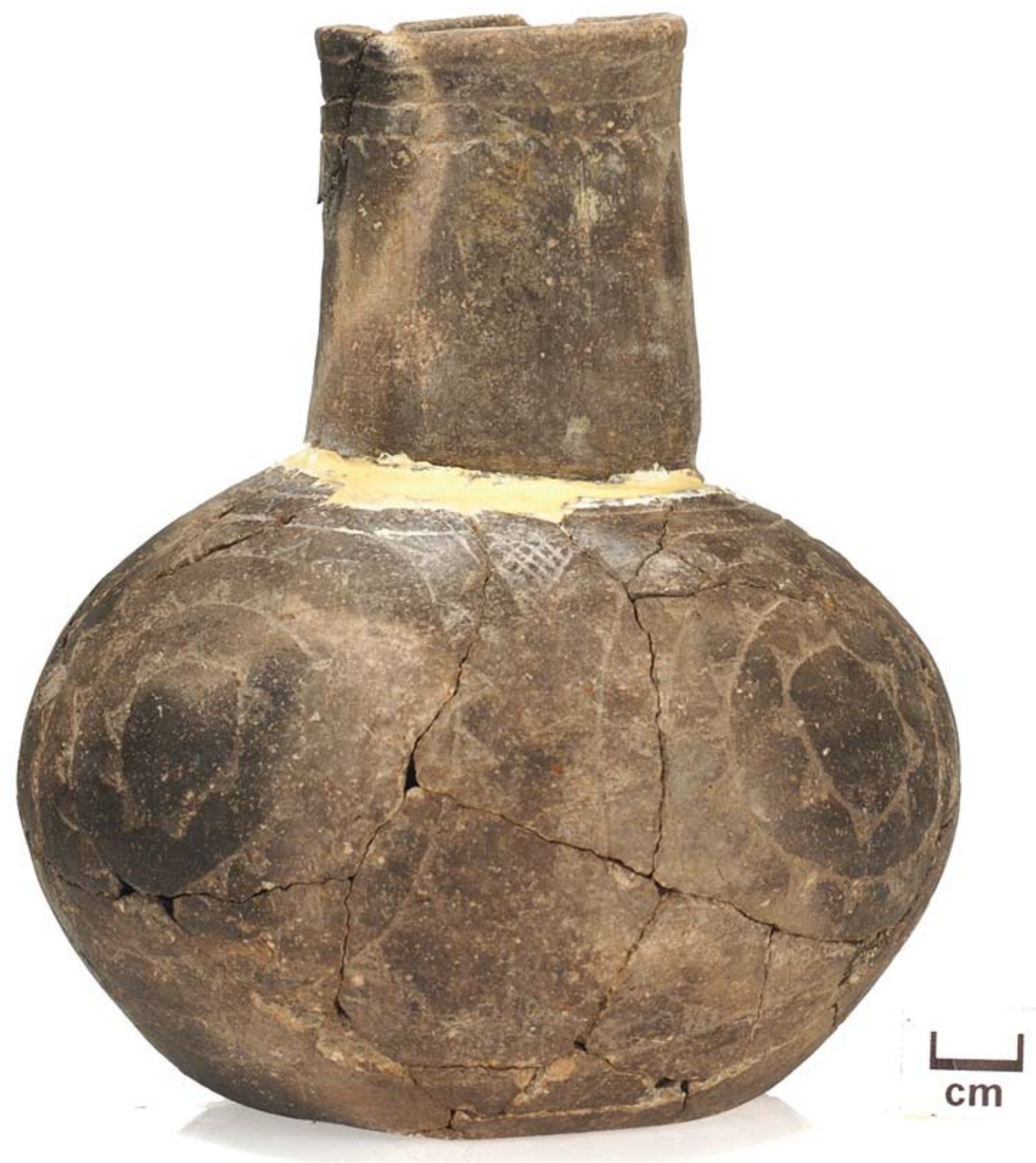

Figure 15. Hempstead Engraved (Vessel 35, Acc. \#: 72-22-1772-29).

Jelks 1962:85). Karnack vessels are often highly firemottled and the cores are colored like the surfaces, if not darker. The interiors are poorly smoothed and the exteriors are roughened by decoration.

Karnack Brushed-Incised vessels have barrelshaped bodies with convex or barely flat bases that "do not stand up well" (Suhm and Jelks 1962:85). The rims are low and slightly turned outward sharply or they may be higher and turned outward less sharply. Wall thicknesses range from 4-7 mm. Karnack vessels are decorated with incising and brushing. The incised lines were made individually or brushed (possibly with grass). These lines run vertically, or nearly vertically, over the whole body of the jar. The rim exteriors have incised 


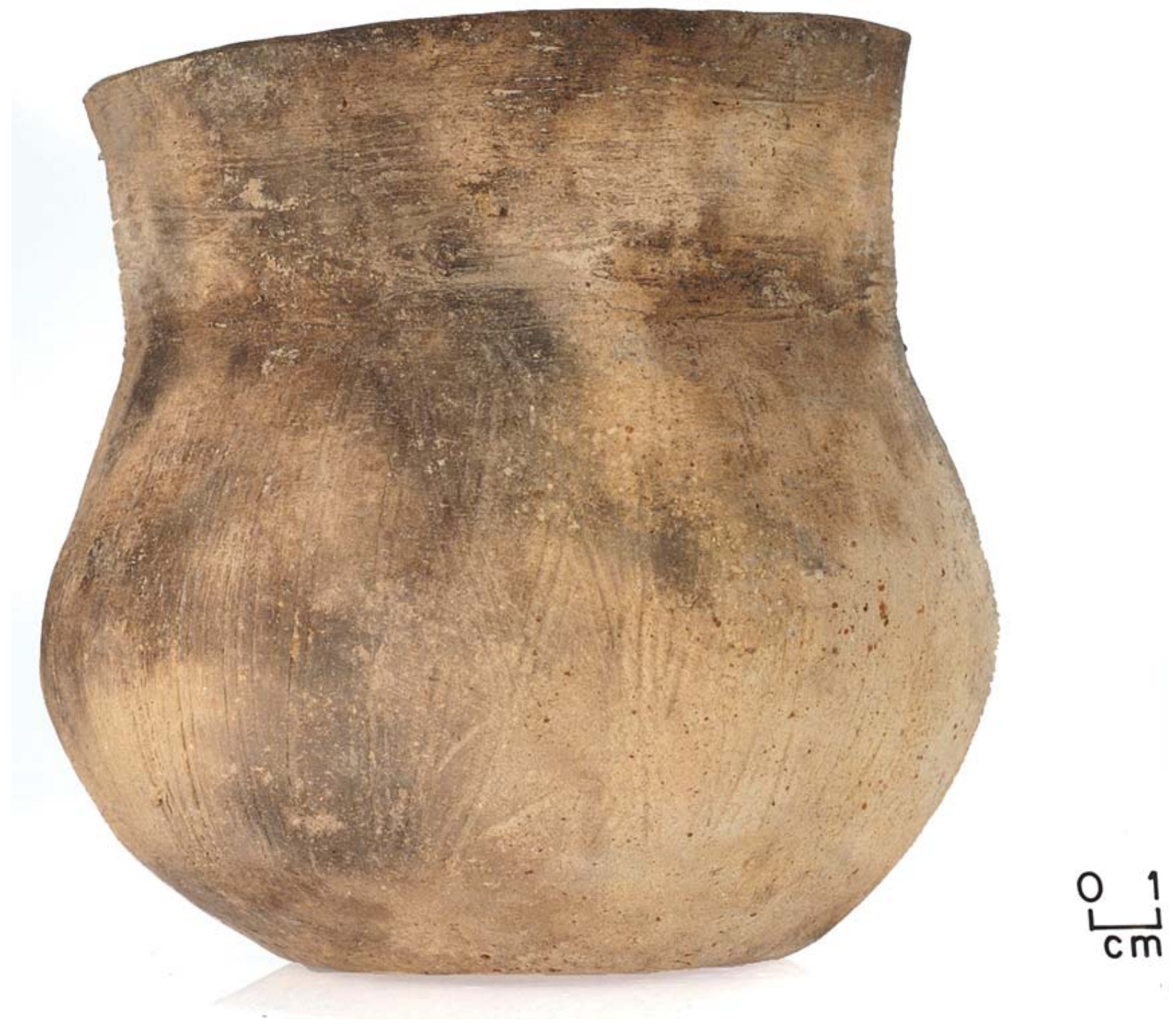

Figure 16. Karnack Brushed-Incised (Vessel 22, Acc. \#: 72-22-1772-7).

lines that run vertically or diagonally or brushed lines running horizontally around the vessel (Suhm and Jelks 1962:85). It is unusual for Karnack Brushed-Incised vessels to have a plain rim.

One Karnack Brushed Incised jar, Vessel 22 (Acc. \#: 72-22-1772-7), was excavated from Burial 21 (Mound B, Feature 8) (Figure 16). The color of this vessel is highly varied due to fire-mottling. The globular jar has a vertical-slightly outcurved rim, a flat lip, and convex and flat bottom. The temper is clay grit and the paste is course and silty. This burial vessel was found nearly complete (only one rim sherd glued back on). This pot is poorly smoothed on the interior and exterior, and the exterior is further roughened by brush-incising.

\section{Kiam Incised}

Kiam Incised is an Early Caddo utilitarian ware with a clay-grit temper, with the occasional addition of bone, carbon, or sand. The texture of these vessels is coarse, ranging from compact to crumbly" (Suhm and Jelks 1962:89). Vessel color ranges from "light yellowishbrown, reddish brown, medium brown and chocolate" (Suhm and Jelks 1962:89). The cores are gray, graybrown, and are the same color as the surface. The surface finish on Kiam Incised vessels ranges from poorly smoothed to polished, except for the decorated parts. 

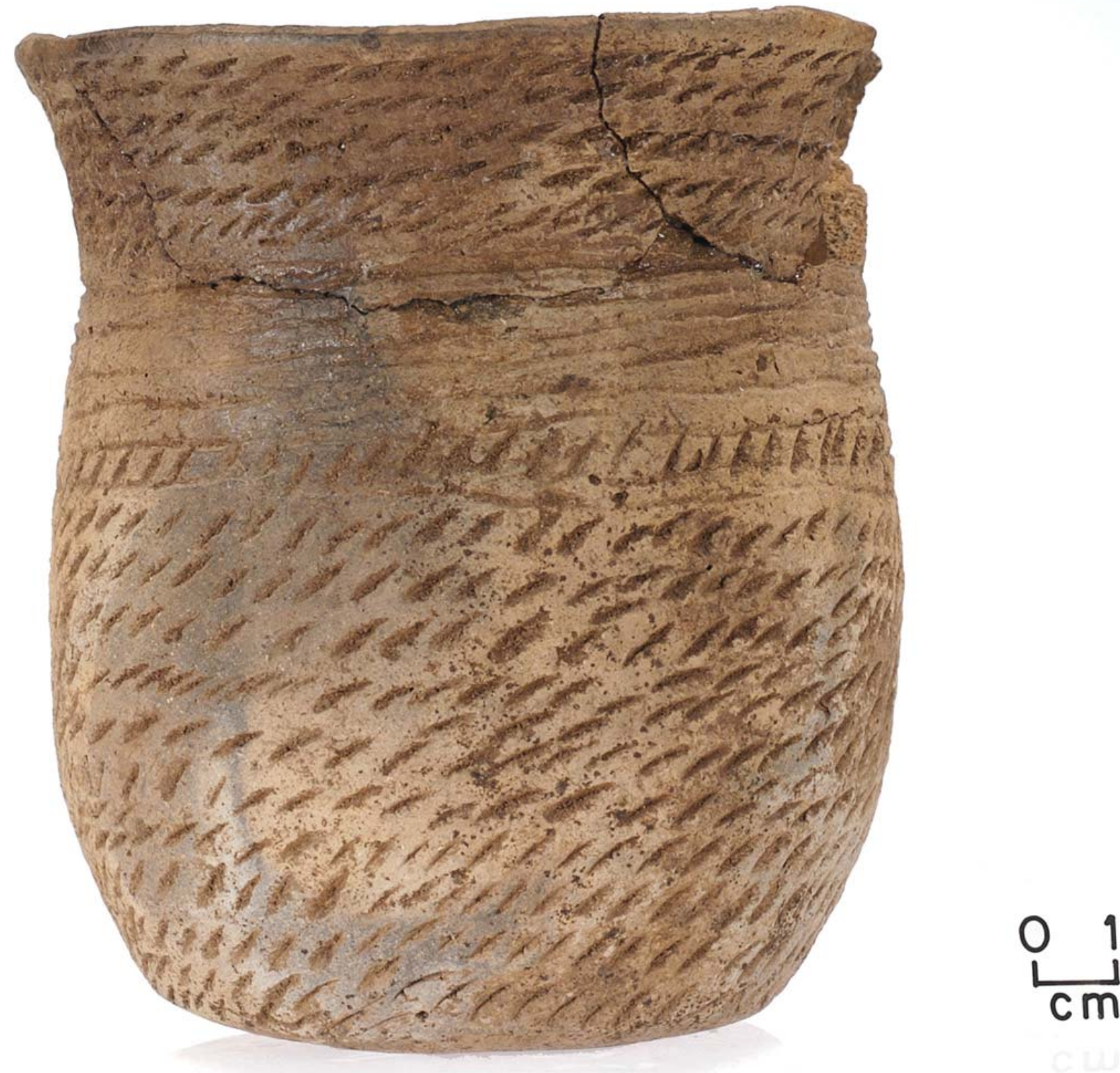

Figure 17. Kiam Incised (Vessel 39, Acc. \#: 74-267-23-2283).

Kiam Incised is primarily composed of "jars with rims vertical to everted...from only about $10 \mathrm{~cm}$. high to as much as $50 \mathrm{~cm}$ or more; the latter are fairly numerous and may be regarded as storage jars" (Suhm and Jelks 1962:89). Kiam Incised vessels have fingernail punctations and incising as their main decorative elements. In rare cases, stick punctating was also used. The designs include horizontal lines encircling the rim on all vessels. This is "rather crudely done, lines do not 'overhang"' (Suhm and Jelks 1962:89). The bodies are occasionally plain but are usually vertically incised, and as closely spaced as the rims; or fingernail punctations are arranged across the body in horizontal rows. Appendages are absent on Kiam vessels.

One Kiam Incised jar, Vessel 39 (Acc. \#: 74-267-23-2283) was recovered from Burial 9 (Plot 2, Feature 18) (Figure 17). This jar has tool or fingernail punctates around both the body and rim, which are separated by a band of brushed-incised elements encircling the boundary between them. The presence of this type in Burial 9 may indicate an Early Caddo period use of the Plot 2 area of the Ferguson site, preceding the Middle Caddo Haley phase burials associated with the Mound $\mathrm{A}$ and $\mathrm{B}$ areas. 


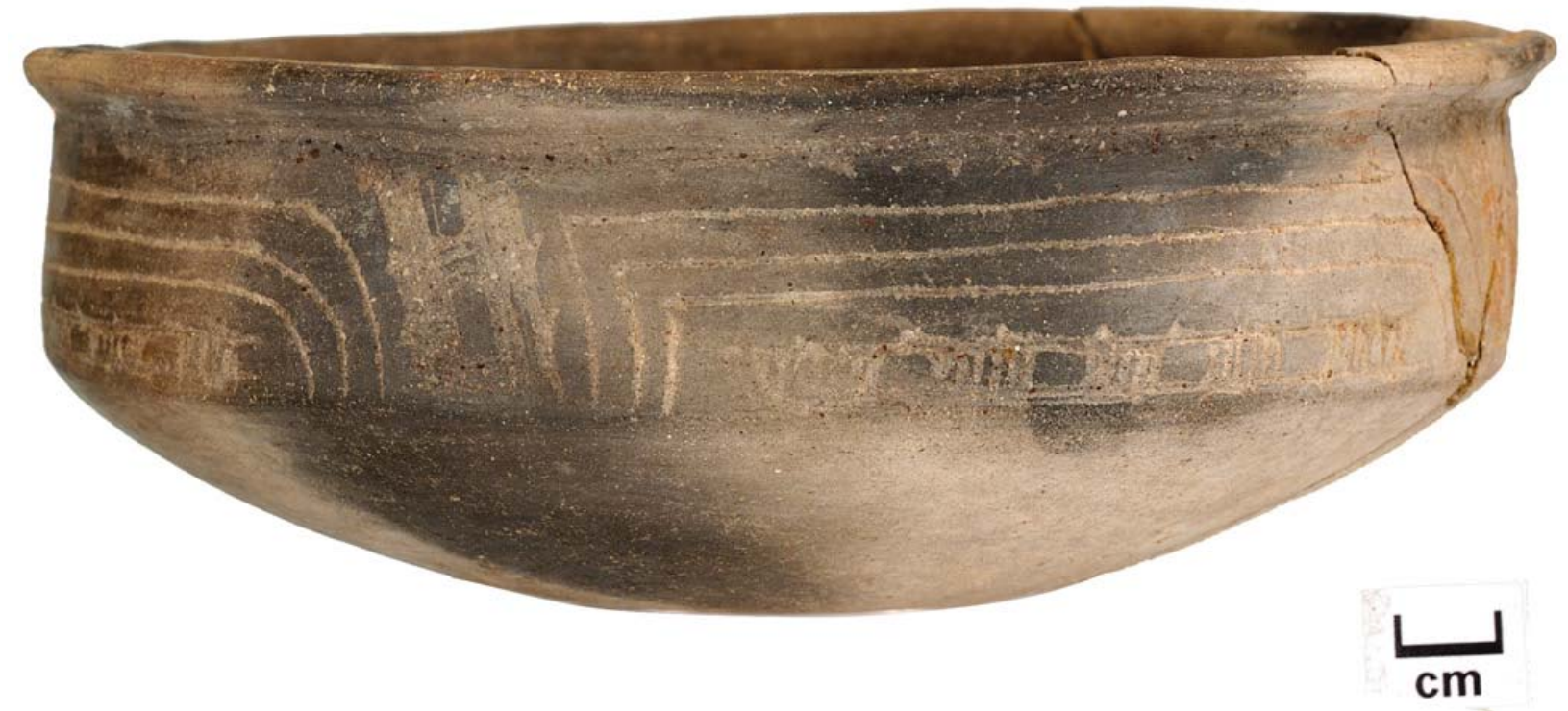

Figure 18. Mineral Springs Engraved (Vessel 25, Acc. \#: 72-22-1772-12).

\section{Mineral Springs Engraved}

Mineral Springs Engraved is a type defined by Schambach "as characterized by patterns of concentric lines made up of 'ladderlike' elements" (Brown 1996:379). Vessels of this type were originally assigned to the Maddox Engraved type (see Webb 1959; Brown 1971; Bohannon 1973). One of the five carinated bowls from Burial 21 (Mound B, Feature 8) (Acc. \#: 72-22-1772-12) is of the Mineral Springs Engraved type (Figure 18). This carinated bowl has an insloping slightly incurved rim, rolled septogonal lip, and circular and convex base. The vessel is grit with some bone temper and has a hard and silty paste. The body has four design fields filled with engraved lines with crushed red hematite within the lines.

\section{Moore Noded}

Moore Noded was named by Lynn Howard in an unpublished manuscript on the Battle site about a local version of the Lower Mississippi Valley type, Fortune Noded (Phillips et al. 1951:120, see Bohannon 1973:120; see other examples in Webb 1959:120, Harrington 1920: Plate XXIIIb). Bohannon (1973:47) listed two vessels from the Mineral Springs site as Moore Noded. These vessels were medium to crumbly coarse-grit bowls decorated with nodes on the body, arranged in regular groups below the lip or placed randomly. The surfaces were reddish-brown and the cores were brown to grey. These vessels had flat bases round and flush with rim lips that were $8 \mathrm{~mm}$ in thickness.

Moore Noded var. Ferguson. One noded vessel, Vessel 21 (Acc. \#: 72-22-1772-5), recovered from Burial 21 (Mound B, Feature 8) at Ferguson differs from these other examples of Moore Noded in several ways. These differences define the new Moore Noded var. Ferguson (Figure 19). The body decoration is divided into six vertical panels, alternating between three noded and three punctated panels (two horizontal and one diagonal). The rim is everted and is brushed horizontally. The temper includes significant quantities of bone along with clay and grit.

\section{Pease Brushed Incised}

Pease Brushed Incised is a Caddo coarseware that has a clay-grit temper, including occasional pulverized bone pieces (Suhm and Jelks 1962:119: Plate 60). The texture is granular, with medium-sized particles. Surface colors include shades of buff, light gray, occasionally dark gray to black with mottling due to uneven firing. The core is usually darker than the surface. The interior surface is smoothed while the exterior is roughened 


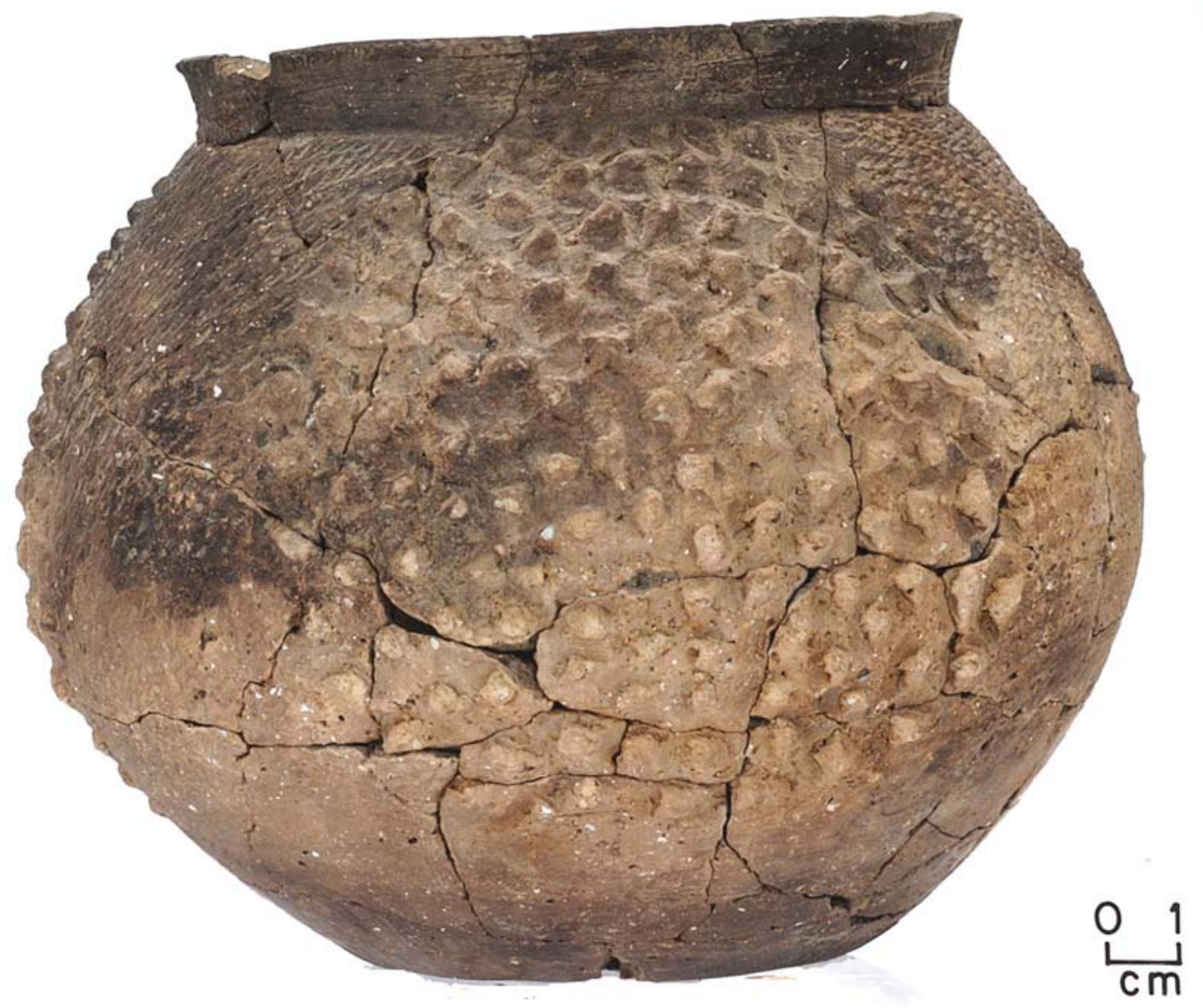

Figure 18. Moore Noded var Ferguson (Vessel 21, Acc. \#: 72-22-1772-5).

by decoration. The vessel form is exclusively jars with slightly outflaring rims varying considerably in height. The oral diameter is usually less than that of the body. Most known specimens are between 12-24 cm in height. Originally, no very large examples or miniature vessels were noted within this type.

Pease Brushed Incised vessel decorations include "incising, brushing, appliqué, and punctation in various combinations" (Suhm and Jelks 1962:119). Designs covered the entire exterior, except the base. The body is divided into panels with vertical appliqued fillets or rows of punctates, or punctates made in appliqued fillets (appliqued fillets are punctated - that is what makes them fillets). There is no consistent number of panels, which varies from six to twenty or more. The panels are "filled with brushing or parallel incised lines set diagonally in alternating directions with 'herringbone' effect" (Suhm and Jelks 1962:119). Lines are often deeper at one end over the other. The rim decoration is similar, "except brushing or incised lines may run in different directions from those on body" (Suhm and Jelks 1962:119). There is almost always at least one row of punctates around the rim that has been made through the brushed or incised lines. Often, "there are two or more such rows, one just under the lip, one around the middle of the rim, and perhaps one at the base of the rim" (Suhm and Jelks 1962:119).

One Pease Brushed Incised jar, Vessel 5 (Acc. \#: 72-22-101-5), was recovered from the group shaft grave in Burial 1-4 at Ferguson (Figure 20). Another 


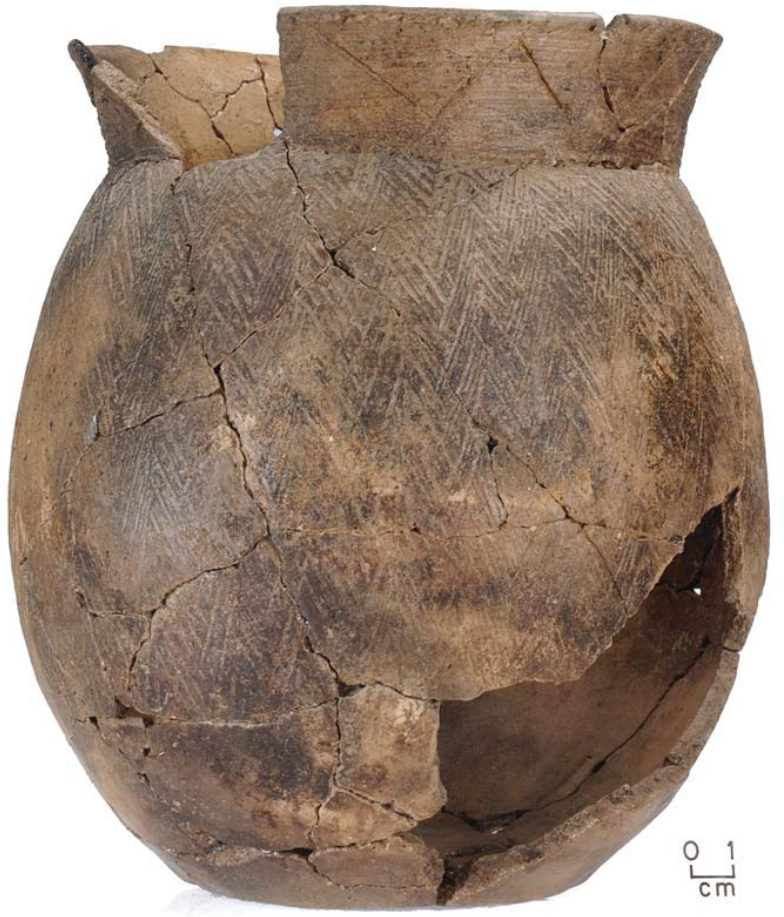

Figure 20. Pease Brushed Incised (Vessel 5, Acc. \#: 72-22-1015)

jar from this grave (Acc. \#: 72-22-101-9), has a Pease Brushed Incised body decoration and a Sinner Linear Punctated rim. This oval bodied jar has an outsloping rim, slightly everted lip, and circular convex base. It has a clay temper and a soft, fine, and compact paste. This Pease Brushed Incised Jar is one of four large jars interred with the Mound B, Feature 2 burials. A small Pease Incised-like (not brushed) cup or jar was found associated near the skull of Burial 1 in this grave. Schambach has suggested the type Chance Incised for this and similar small incised jars (personal communication June 2010). Additionally, a large three gallon Pease Brushed Incised jar with a convex base was also found crushed on the floor of the Feature 6-8 house, a daub-covered square or rectangular temple structure that was intentionally burned on Mound A (Figure 21) (see Schambach 1972a, 1996; Schambach and Early 1985).

\section{Sinner Linear Punctate}

Sinner Linear Punctate ceramic vessels are a Caddo utilitarian ware with a clay-grit temper, with some pulverized bone (Suhm and Jelks 1962:143). The texture

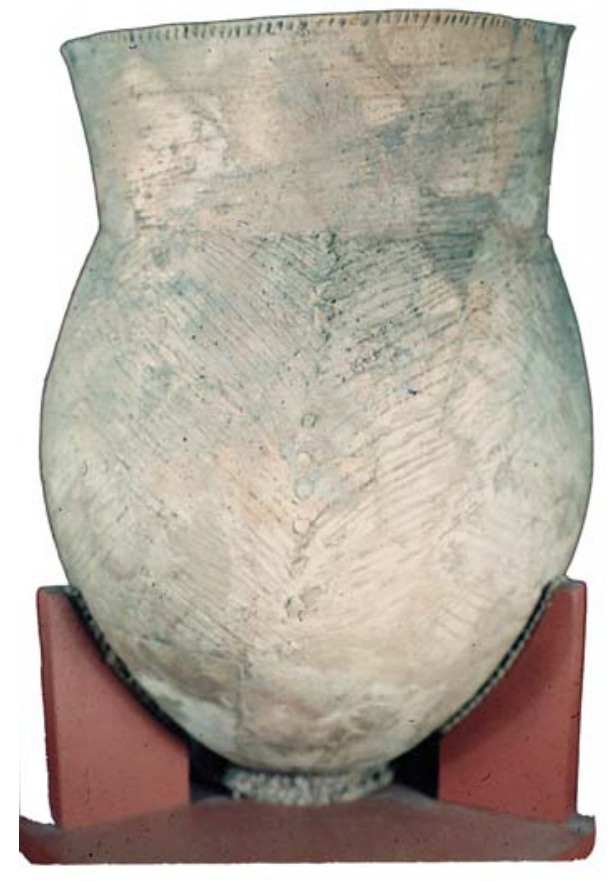

Figure 21. Pease Brushed Incised Jar from Mound A, Feature 6-8 floor.

is fine and compact, while the color includes surfaces with cream, buff, shades of brown and gray, to nearly black in fire-mottled areas. The cores tend to be the same color as surfaces or darker. Sinner Linear Punctate vessels are typically composed of small jars about 10-15 $\mathrm{cm}$ high, with vertical to everted rims meeting the body at a slight angle. They have globular bodies with rims "varying from low and everted to high and vertical" (Suhm and Jelks 1962:143).

Decorations on this type include punctating and appliqued nodes or ridges. Bodies and rims are "almost completely covered with punctations set close together in closely spaced rows, so regular as to give the suggestion of cord marking" (Suhm and Jelks 1962:143). These punctations are made either individually with small round-tipped tools or are made in rows with a carved stamp. Though infrequent, the tip of the fingernail is also used to make the punctations. The rows of decoration "are arranged in parallel sets, pitched at different angles and either straight or slightly curved" (Suhm and Jelks 1962:143). This is sometimes broken into four design panels with rows of nodes or fillets running vertically on the body. 


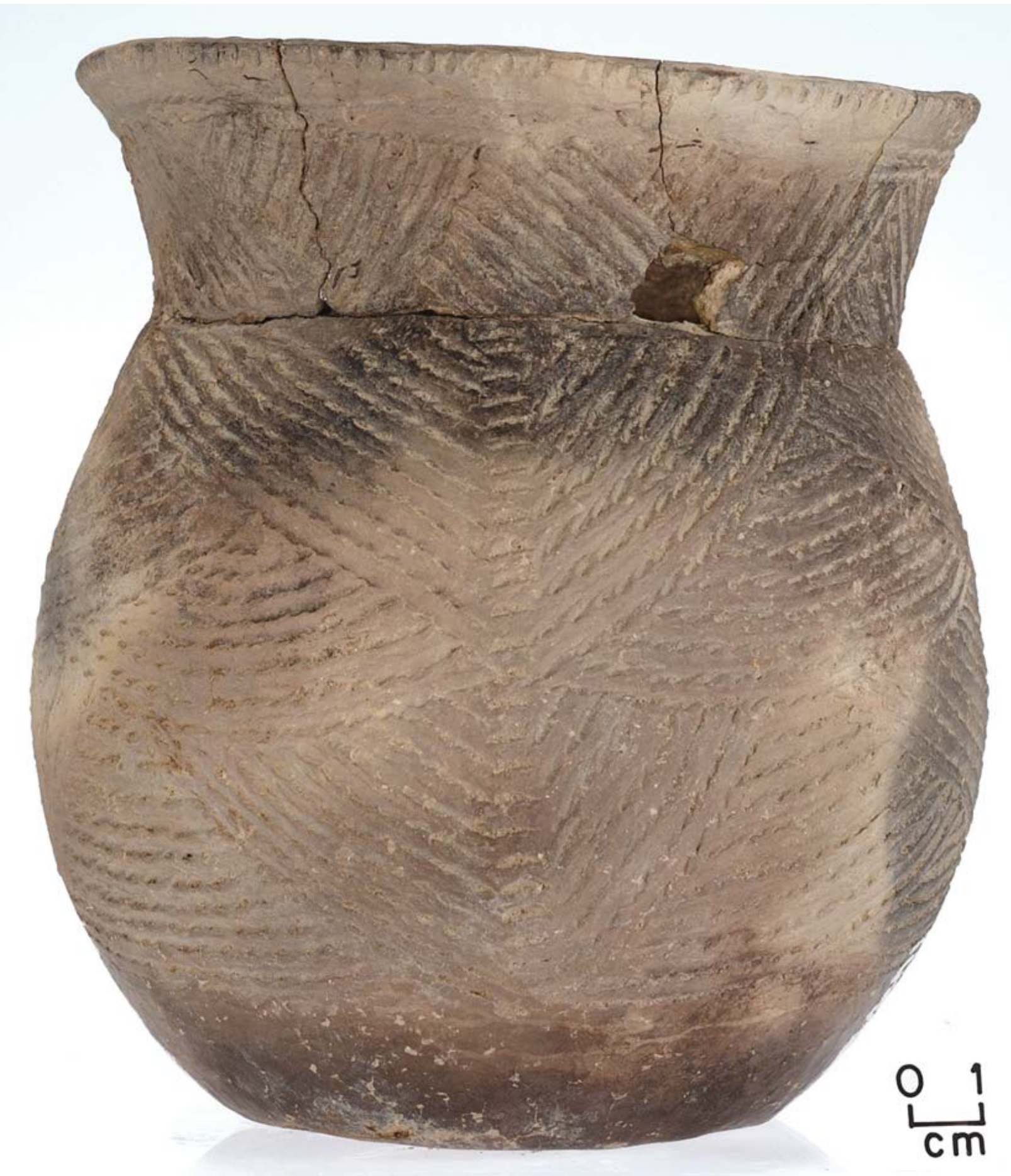

Figure 22. Sinner Linear Punctate (Vessel 16, Acc. \#: 72-22-341-04).

Eight Sinner Linear Punctate jars and one jar with a Sinner rim and Pease Brushed Incised body were recovered from Ferguson. The dual type jar and two others were from Burial 1-4 (Mound B, Feature 2), three were from Burial 21 (Mound B, Feature 8), and two were from Burial 5 (Mound B, Feature 32). Ferguson Vessel 16 (Acc. \#: 72-22-341-04) is a globular enlongated jar with an outsloping incurved rim, slightly rolled lip, a globular elongated body, and circular and convex base (Figure 22). This jar has dark areas from 


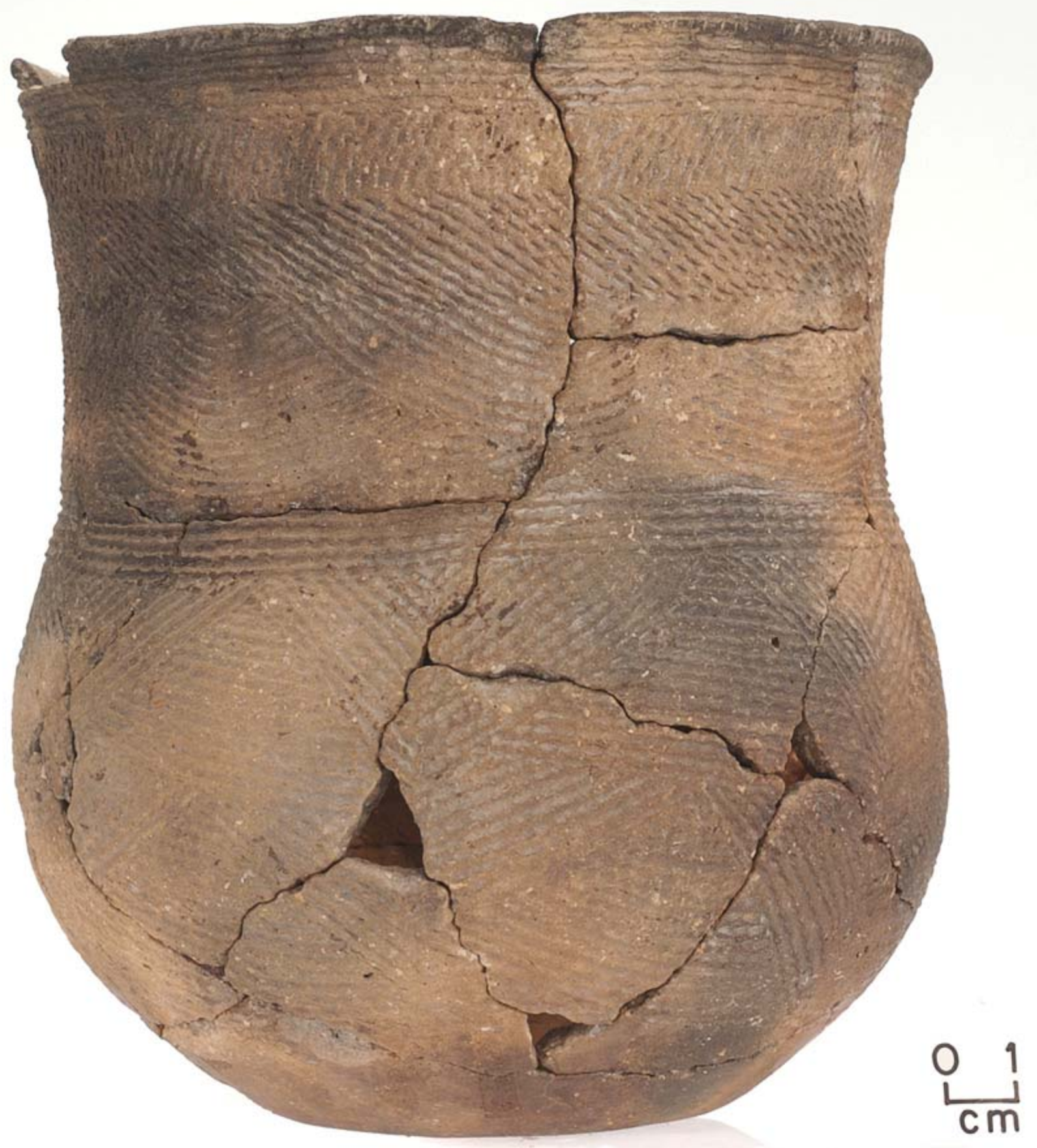

Figure 23. Sinner Linear Punctate (Vessel 9, Acc. \#: Acc. \#: 72-22-101-10).

possible fire mottling, is grit and bone tempered, and has a hard and compact paste. This vessel is the larger of two Sinner Linear Puncate jars from Burial 5 (Mound B, Feature 32).

Ferguson Vessel 09 (Acc. \#: 72-22-101-10) is associated with the Burial 1-4 group (Mound B,
Feature 2) (Figure 23). This globular elongated jar has a vertical and slighty outsloping rim, slightly rolled lip, globular and elongated body, and a pedestal outsloping side base meeting a circular and flat to convex, with minimum curvature on the bottom. This vessel has a clay temper and a soft, fine, and compact paste. 


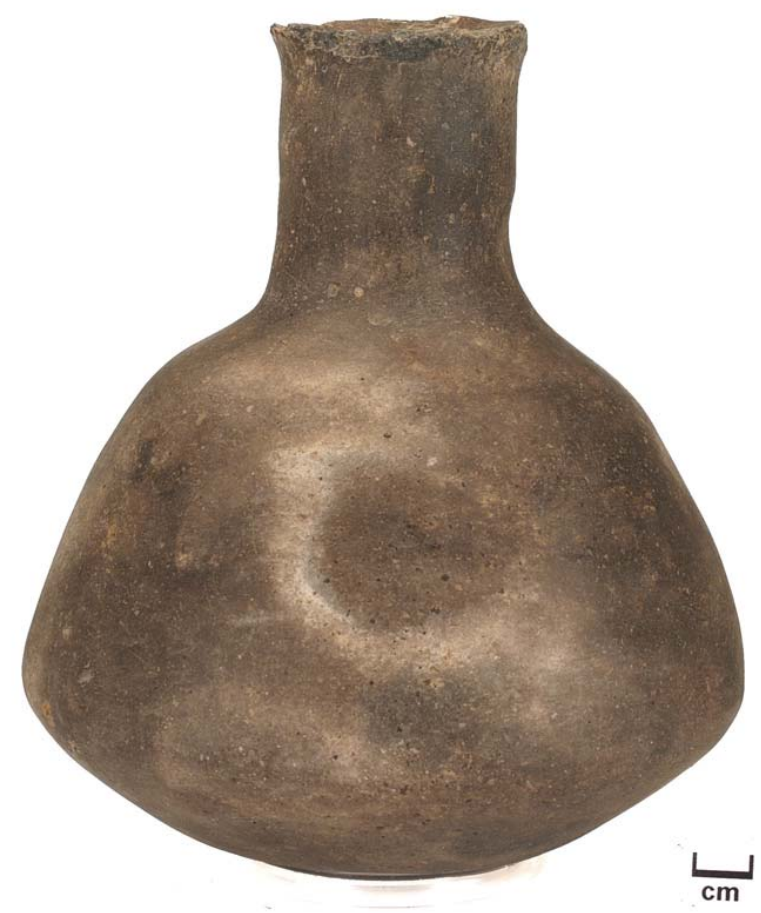

Figure 24. Untyped plain bottle (Vessel 40, Acc. \#: 73-1172058-1).

\section{Untyped Pottery Vessels}

Vessels 40 (Acc \#: 73-117-2058-1) and 41 (Acc \#: 73-117-2058-2) are a pair of plain bottles found with Burial 14 in an ancestral Caddo-Fourche Maline grave, discovered off-mound in Plot 2, Feature 6 (Figures 24 and 25). A quartz crystal (Acc \#: 72-117-2058-3) was also found within the grave goods in Burial 14. These Woodland period bottles are very thick compared to the Middle Caddo vessels in the rest of the Ferguson site whole vessel assemblage. No visible decorations are present on either bottle.

Vessel 46 (Acc. \#: 72-22-1772-06) is an untyped Middle Caddo small bottle recovered from Burial 21 (Mound B, Feature 8). Doubled-lined X's are engraved around the circumference of the bottle. These X's are filled with smaller X's or chevrons. Some downfacing chevrons around the top of body are filled with tool-marked ticks. This vessel may represent an atypical example of the Hempstead Engraved type.

\section{Summary and Discussion}

The Haley phase marked the appearance of ceramic features within the Middle Caddo period such "as the

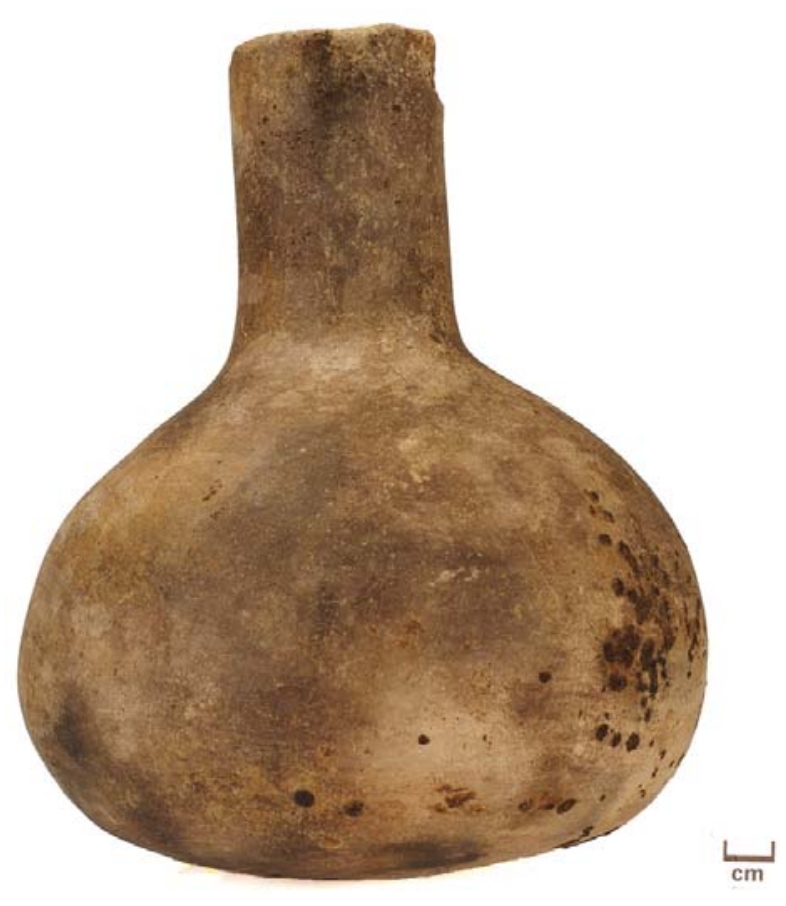

Figure 25. Untyped plain bottle (Vessel 41, Acc. \#: Acc \#: 73117-2058-2).

use of handles (wide strap handles on polished bowls as well as cooking jars), appliqué fillets and nodes, brushing on jar surfaces as alternative to incising, fairly extensive use of red filming, and effigy vessels" (Suhm and Jelks 1962:171). These elements are very rare on pottery vessels from the Spiro, Gahagan, and Alto sites.

Numerous elite Caddo shaft graves excavated at Ferguson contained whole ceramic vessels diagnostic of the Haley phase A total of 42 whole ceramic vessels were documented and analyzed as a part of this study. Caddo pottery types in the Ferguson site assemblage include Adair Engraved ( $\mathrm{n}=1)$, East Incised ( $\mathrm{n}=1)$, Friendship Engraved ( $\mathrm{n}=5)$, Glassell Engraved $(\mathrm{n}=2)$, Haley Complicated Incised ( $\mathrm{n}=2$ ), Haley Engraved $(\mathrm{n}=10)$, Hempstead Engraved ( $\mathrm{n}=3)$, Karnack Brushed Incised ( $\mathrm{n}=1)$, Kiam Incised ( $\mathrm{n}=1)$, Moore Noded $(\mathrm{n}=1)$, Pease Brushed Incised ( $\mathrm{n}=2)$, Sinner Linear Punctate $(\mathrm{n}=7)$, a combination Pease Brushed Incised and Sinner Linear Punctate $(\mathrm{n}=1)$ vessel, and three that are untyped $(n=3)$. Vessel forms included bottles, bowls, and jars.

These whole vessels originated in numerous burial features around the site including: Burial 1-4 (Mound B, Feature 2), Burial 21 (Mound B, Feature 8), Burial 5 (Mound B, Feature 32), Burial 12 (Mound B, Feature 14/15), Burial 14 (Plot 2, Feature 6), Burial 11 
(Plot 3, Feature 8), and Burial 9 (Plot 2, Feature 18). Fifty percent of the vessels $(n=21)$ originated in Burial 21 alone, an elite Caddo shaft grave intrusive in the center of Mound B. Nearly another third of the whole vessels collection came from the Burial 1-4 group shaft grave. Burial 5 was another contemporaneous Caddo grave and had four whole vessels. Burial 9, 12, and 14 each contained a single whole vessel from the Middle Caddo period as well. Finally, Burial 14 was a Woodland period grave that had two untyped plain bottles.

\section{Acknowledgements}

Thank you to the Arkansas Archeological Survey for allowing me to study the Ferguson site collection. Dr. Jamie Brandon generously offered access to the collection and site records from the Southern Arkansas University-Arkansas Archeological Survey Station, along with support and encouragement throughout the analysis. All data on the Caddo of Ferguson would have been lost if not for years of excavation conducted by the Survey and Arkansas Archeological Society, under the direction of Dr. Frank Schambach. His meticulous fieldwork, notes and generously shared memories make the presentation and preservation of these data possible. Thank you to Dr. Ann Early who guided me with the Collegiate Style Descriptive Classification rim and body designs of the Ferguson vessels. Thank you to Dr. George Sabo III who read and commented on an earlier version of this paper. Finally, thank you to Jane Kellett for photographing the Ferguson site vessels.

\section{References Cited}

Bohannon, Charles F.

1973 Excavations at the Mineral Springs Site, Howard County, Oklahoma. Research Series No. 5. Arkansas Archeological Survey, Fayetteville.

Brown, James A.

1971 Approaches to the Social Dimensions of Mortuary Practice. Society for American Archaeology Memoir, 1. Washington, DC, Society for American Archaeology.
1996 The Spiro Ceremonial Center, Memoirs of the Museum of Anthropology. University of Michigan, Ann Arbor, Michigan: Museum of Anthropology Publications.

Early, Ann. M. (editor)

1988 Standridge: Caddoan Settlement in a Mountain Environment. Research Series No. 29. Arkansas Archeological Survey, Fayetteville.

1989 Form and Structure in Ceramic Design: a case study from the Caddo area. Paper presented at the 46th Southeastern Archaeological Conference, Tampa.

1993 Caddoan Saltmakers in the Ouachita Valley: The Hardman Site. Research Series No. 43. Arkansas Archeological Survey, Fayetteville.

2000 Forest Farmsteads: A Millennium of Human Occupation at Winding Stair in the Ouachita Mountains. Research Series 57. Arkansas Archeological Survey, Fayetteville.

Harrington, Mark R.

1920 Certain Caddo sites in Arkansas. Museum of the American Indian, Heye Foundation, New York.

Hart, John P. and Timothy K. Perttula

2010 The Washington Square Mound Site and a Southeastern Ceremonial Complex Style Zone among the Caddo of Northeastern Texas. Midcontinental Journal of Archaeology 5(2):199228

Hoffman, Michael. P.

1967 Ceramic Pipe Style Chronology Along the Red River Drainage in Southwestern Arkansas. The Arkansas Archeologist 8(1):4-14.

1971 A Partial Archeological Sequence for the Little River Region, Arkansas. Ph.D. dissertation, Department of Anthropology, Harvard University, Cambridge. 
Khawam, Rhoula

2003 Documentation of Ceramic Vessels as part of NAGPRA grant. Document on file the Arkansas Archeological Survey, Fayetteville.

Kreiger, Alex D.

1946 Culture Complexes and Chronology in Northern Texas. University of Texas Publication 4640, Austin.

McKinnon, Duncan P.

2008 An Archaeogeophysical Analysis of Central Caddo Settlement Patterning at Battle Mound (3LA1). Master's thesis, Department of Anthropology, University of Arkansas, Fayetteville.

2009 Exploring Settlement Patterning at a Premier Caddo Mound Site in the Red River Great Bend Region. Southeastern Archaeology 28(2):248-258.

2010a Summer 1948: A Summary of Excavations at Battle Mound (3LA1), A Premier Caddo Mound Site in the Great Bend Region of the Red River. The Arkansas Archeologist 49:1-16.

2010b Continuing the Research: Archaeogeophysical Investigations at the Battle Mound Site (3LA1) in Lafayette County, Arkansas Southeastern Archaeology 29(2):250-260.

2013 Battle Mound: Exploring Space, Place, and History of a Red River Caddo Community in Southwest Arkansas. Ph.D. dissertation, Department of Anthropology, University of Arkansas, Fayetteville.

2017 The Battle Mound Landscape: Exploring Space, Place, and History of a Red River Caddo Community in Southwest Arkansas. Research Series No. 68. Arkansas Archeological Survey, Fayetteville.

Moore, Clarence Bloomfield

1912a Certain mounds of Arkansas and of Mississippi. Journal of the Academy of Natural Sciences of Philadelphia. 1912b Some Aboriginal Sites on Red River. Journal of the Academy of Natural Sciences of Philadelphia 14(4):526-636.

Newell, H. Perry and Alex D. Krieger

1949 The George C. Davis Site, Cherokee County, Texas. Memoirs No. 5. Society for American Archaeology, Menasha, Wisconsin.

Perttula, Timothy K.

1992 "The Caddo Nation": Archaeological and Ethnohistoric Perspectives. The University of Texas Press, Austin.

1996 Caddoan Area Archaeology Since 1990. Journal of Archaeological Research 4:295-348.

1998 Late Caddoan Societies in the Northeast Texas Pineywoods. In The Native History of the Caddos: Their Place in Southeastern Archeology and Ethnohistory, edited by Timothy K. Perttula and James. E. Bruseth, pp. 69-90. Studies in Archeology 30. Texas Archeological Research Laboratory, The University of Texas at Austin.

2005 1938-1939 WPA Excavations at the Hatchel Site (41BW32) on the Red River in Bowie County, Texas. Southeastern Archaeology 24(2):180-198.

Perttula, Timothy K. and Chester P. Walker (editors) 2012 The Archaeology of the Caddo. University of Nebraska Press, Lincoln.

Perttula, Timothy K., Chester P. Walker, and T. Clay Schultz

2008 A Revolution in Caddo Archaeology: The Remote Sensing and Archaeological View from the Hill Farm Site (41BW169) in Bowie County, Texas. Southeastern Archaeology 27(1):93-107.

Phillips, Phillip and James A. Brown

1978 Pre-Columbian Shell Engravings from the Craig Mound at Spiro, Oklahoma, Part 1. Cambridge. Peabody Museum. Press, Boston, Massachusetts. 
1984 Pre-Columbian Shell Engravings from the Craig Mound at Spiro, Oklahoma, Part 2. Cambridge. Peabody Museum. Press, Boston, Massachusetts.

Phillips, Philip, James A. Ford, and James B. Griffin

1951 Archaeological Survey in the Lower Mississippi Alluvial Valley, 1940-1947. Papers of the Peabody Museum of American Archaeology and Ethnology, Harvard University, Volume 25. Cambridge, Massachusetts.

Rice, Prudence M.

1987 Pottery analysis: A Source Book. University of Chicago Press, Chicago.

Rose, Jerome C. and Mary L. Powell

1975 Skeletal Analysis of the Ferguson Site. Department of Anthropology and Sociology, University of Alabama Birmingham. Unpublished report on file at the Arkansas Archeological Survey.

Schambach, Frank F.

1972a Preliminary Report on the 1972 Excavations at the Ferguson Site (3HE63). The Arkansas Archeologist 13(1-2):1-13.

1972b Unpublished Field Notes from 1972 Excavations. Arkansas Archeological Survey, Fayetteville.

1973 Unpublished Field Notes from 1973 Excavations. Arkansas Archeological Survey, Fayetteville.

1974 Unpublished Field Notes from 1974 Excavations. Arkansas Archeological Survey, Fayetteville.

1996 Mounds, Embankments, and Ceremonialism in the Trans-Mississippi South. In Mounds, Embankments, and Ceremonialism in the Midsouth, edited by Robert C. Mainfort and Richard Walling, pp. 36-43. Research Series No. 46. Arkansas Archeological Survey, Fayetteville.

1997 The Development of the Burial Mound Tradition in the Caddo Area. Journal of Northeast Texas Archaeology 9:53-72.
1998 Pre-Caddoan Cultures of the Trans-Mississippi South. Research Series 53. Arkansas Archeological Survey, Fayetteville.

Schambach, Frank F. and Ann M. Early

1985 Late Caddo Culture (Caddo III-IV). Pictures of Record Inc., Weston, Connecticut.

Shepard, Anna O.

1956 Ceramics for the Archaeologist. Carnegie Institution of Washington, Washington, D.C.

Suhm, Dee Ann, Edward B. Jelks, and Alex D. Krieger 1954 An Introductory Handbook of Texas Archeology. Bulletin 25 of the Texas Archeological Society.

1962 An Introductory Handbook of Texas Archeology. Texas Archeological Society.

Webb, Clarence H.

1959 The Belcher Mound: A Stratified Caddoan Site in Caddo Parish, Louisiana. Memoirs of the Society for American Archaeology, No. 16.

Wyckoff, Don G.

1974 The Caddoan Cultural Area; An Archaeological Perspective. In Caddoan Indians I, pp. 25- 279. Garland Publishing, Inc., New York.

Wyckoff, Don G. and Timothy Baugh

1980 Early Historic Hasinai Elites: A Model for the Material Culture of Governing Elites. Midcontinental Journal of Archaeology 5, 225283. 